\title{
Reconciling the stratigraphy and depositional history of the Lycian orogen-top basins, SW Anatolia
}

\author{
M. Cihat Alçiçek ${ }^{1}$ - Serdar Mayda ${ }^{2}$ • Johan H. ten Veen ${ }^{3} \cdot$ Sarah J. Boulton $^{4} \cdot$ Thomas A. Neubauer $^{5,6}$ • Hülya Alçiçek ${ }^{1}$.

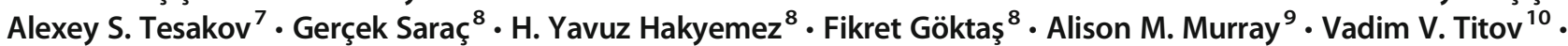 \\ Gonzalo Jiménez-Moreno ${ }^{11}$ - Yeşim Büyükmeriç ${ }^{12}$ • Frank P. Wesselingh ${ }^{6}$ • Johannes M. Bouchal ${ }^{13,14}$. \\ F. Arzu Demirel ${ }^{15} \cdot$ T. Tanju Kaya ${ }^{2} \cdot$ Kazım Halaçlar ${ }^{2,16,17}$ • Melike Bilgin ${ }^{6,18} \cdot$ Lars W. van den Hoek Ostende $^{2,6}$
}

Received: 18 May 2018 / Revised: 24 October 2018 / Accepted: 5 March 2019 / Published online: 3 August 2019

(C) The Author(s) 2019

\begin{abstract}
Terrestrial fossil records from the SW Anatolian basins are crucial both for regional correlations and palaeoenvironmental reconstructions. By reassessing biostratigraphic constraints and incorporating new fossil data, we calibrated and reconstructed the late Neogene and Quaternary palaeoenvironments within a regional palaeogeographical framework. The culmination of the Taurides in SW Anatolia was followed by a regional crustal extension from the late Tortonian onwards that created a broad array of NE-trending orogen-top basins with synchronic associations of alluvial fan, fluvial and lacustrine deposits. The terrestrial basins are superimposed on the upper Burdigalian marine units with a c. 7 myr of hiatus that corresponds to a shift from regional shortening to extension. The initial infill of these basins is documented by a transition from marginal alluvial fans and axial fluvial systems into central shallow-perennial lakes coinciding with a climatic shift from warm/humid to arid conditions. The basal alluvial fan deposits abound in fossil macro-mammals of an early Turolian (MN11-12; late Tortonian) age. The Pliocene epoch in the region was punctuated by subhumid/humid conditions resulting in a rise of local base levels and expansion of lakes as evidenced by marsh-swamp deposits containing diverse fossil mammal assemblages indicating late Ruscinian (late MN15; late Zanclean) age. A second pulse of extension, accompanied by regional climatic
\end{abstract}

This article is a contribution to the special issue "Taking the Orient Express? The role of Anatolia in Mediterranean Neogene palaeobiogeography"

Johannes M. Bouchal

Johannes.Bouchal@nrm.se

M. Cihat Alçiçek

alcicek@pau.edu.tr

1 Department of Geology, Pamukkale University, 20070 Denizli, Turkey

2 Department of Biology, Ege University, 35100 Izmir, Turkey

3 TNO-Geological Survey of the Netherlands, Princetonlaan 6, 3584 CB Utrecht, The Netherlands

4 School of Geography, Earth \& Environmental Sciences, Plymouth University, Plymouth PL4 8AA, UK

5 Department of Animal Ecology \& Systematics, Justus Liebig University, 35392 Giessen, Germany

6 Naturalis Biodiversity Center, P.O. Box 9517, 2300 RA Leiden, The Netherlands

7 Geological Institute, Russian Academy of Sciences, Staromonetny per., Moscow, Russia 119017

8 General Directorate of the Mineral Research \& Exploration of Turkey (MTA), Ankara, Turkey
9 Department of Biological Sciences, University of Alberta, Edmonton T6G 2E9, Canada

10 Southern Scientific Centre, Russian Academy of Sciences, Rostov-on-Don, Russia 344006

11 Departamento de Estratigrafía y Paleontología, Univ. de Granada, Fuente Nueva s/n, 18002 Granada, Spain

12 Department of Geology, Bülent Ecevit University, 67100 Zonguldak, Turkey

13 Department of Palaeobiology, Swedish Museum of Natural History, 11418 Stockholm, Sweden

14 Department of Palaeontology, University of Vienna, 1090 Vienna, Austria

15 Department of Anthropology, Mehmet Akif Ersoy University, 15030 Burdur, Turkey

16 University of Chinese Academy of Sciences, Beijing 100049, China

17 Institute of Vertebrate Paleontology \& Paleoanthropology, Chinese Academy of Sciences, Beijing 100044, China

18 Department of Geology \& Palaeontology, Comenius University, 84215 Bratislava, Slovakia 
changes, prompted subsequent deepening of the lakes as manifested by thick and laterally extensive carbonate successions. These lakes, which prevailed c. 1 myr, later shrank due to renewed progradation of alluvial fans and eventually filled up and dried out, reflected by marsh-swamp deposits at the top of a complete lacustrine succession that contains diverse micro-mammal assemblages indicating a latest Villanyian (MN17; Gelasian) age. A third pulse of tectonic reorganisation and associated extension dissected the basins into their present-day configuration from the early Pleistocene onwards under warm/humid climatic conditions. The new age data provide means to correlate deposits across various basins in the region that help to place the basin development into a regional tectonic framework, which can be attributed to the consequence of the well-articulated regional phenomena of slab-tear/detachmentinduced uplift followed by crustal extension and basin formation (late Tortonian), the outward extension of the Aegean arc (early Pliocene) and eventually accompanied by westward extrusion of the Anatolian Plate (early Pleistocene).

Keywords Correlation $\cdot$ Synchronicity $\cdot$ Palaeoenvironments $\cdot$ Mammal $\cdot$ Post-orogeny $\cdot$ Taurides

\section{Introduction}

Collision and convergence of the microplates in the eastern Mediterranean region, owing to the closure of the Neotethys Ocean, resulted in the development of the Tauride Orogen during the Late Cretaceous to middle Miocene and is locally represented by the Lycian Nappes in SW Anatolia (Șengör and Y1lmaz 1981; Özgül 1976, 1984; Hayward and Robertson 1982; Robertson and Dixon 1984; Șengör et al. 1985; Zanchi et al. 1993; Collins and Robertson 1999, 2003; Okay et al. 2001; Ten Veen et al. 2009; Howell et al. 2017; Nemec et al. 2018). Subsequently, in SW Anatolia, the post-orogenic period was subject to crustal extension, which led to the development of a broad array of NE-trending extensional basins containing contemporaneous alluvial fan, fluvial and lacustrine deposits. These depressions were previously postulated as orogen-top basins, which developed through multiple pulses of crustal extension from the late Tortonian onwards as documented by sedimentation patterns, biostratigraphy, geochronology, fault kinematics and morphotectonics (Becker-Platen 1970; Sickenberg and Tobien 1971; Sickenberg et al. 1975; Dumont et al. 1979; Angelier et al. 1981; Lefevre et al. 1983; Price 1989; Price and Scott 1989; Price and Scott 1991, 1994; Paton 1992; Alçiçek 2001; Saraç 2003; Cihan et al. 2003; Ten Veen 2004; Alçiçek et al. 2005, 2006; Westaway et al. 2005; Kaymakç1 2006; Koçyiğit and Deveci 2007; Alçiçek 2007; Platevoet et al. 2008; Alçiçek and Ten Veen 2008; Ten Veen et al. 2009; Karabacak 2011; Över et al. 2010; Över et al. 2013a, b; Över et al. 2016a, b; Alçiçek et al. 2013a, b; Van den Hoek Ostende et al. 2015a, b; Özsayın 2016; Elitez et al. 2017; Büyükmeriç 2017; Pickford 2016; Geraads 2017; Howell et al. 2017; Özalp et al. 2018; Özkaptan et al. 2018; Kaymakç1 et al. 2018).

The terrestrial fossil record from these basins is important for understanding the regional inter-basinal correlations as well as for unravelling their spatio-temporal evolution. The depositional architecture combined with biostratigraphic evidence constrains the timing and evolutionary history of the region. In addition, the sedimentary record in these basins provides vital information for understanding palaeoenvironmental changes during the post- orogenic period, which can then be corroborated by faunal changes controlled by environmental shifts, and subsequently crucial in unravelling the role of Anatolia on faunal migration routes.

Among these basins, only a few of them, such as the Çameli and Eşen basins, have been comprehensively studied whereas others still require detailed analysis. In order to understand the tectono-stratigraphic development of the basins in SW Anatolia, detailed biostratigraphic information for constraining the timing of tectonic events is essential. This requirement stimulates progress in the further exploration of new fossil mammal sites to enhance the accuracy and resolution of terrestrial Neogene stratigraphy in the region. Being located at the crossroads of Eurasia and Africa, Anatolia is in a unique position for studying Neogene and Quaternary ecosystems and for understanding developments in the biogeography of western Eurasia. This includes the environmental shifts and interregional faunal exchanges including the dispersal of Homo throughout the region (Alçiçek 2010, Vialet et al. 2012, Alçiçek et al. 2017a, Krijgsman et al. 2019). Therefore, fossil faunas and floras from these localities are crucial for these terrestrial basins, as they provide invaluable data for understanding the stratigraphic, palaeoenvironmental and palaeogeographical evolution of the region.

In this context, the primary aim of this study is to fine-tune the stratigraphic framework and to increase the resolution of timing of geodynamic events related to the deformation history of the eastern Mediterranean. This comparative study is a contribution towards a broader understanding of the development of extensional basins array on top of the Lycian Nappes in SW Anatolia and provides new insights into the tectonic history of the region, with analogies drawn with other branches of the Alpine orogen.

\section{Regional geological setting}

The eastern Mediterranean region underwent diverse geodynamical processes linked to the syn-tectonic development 
of both perisutural (foreland) and episutural (thrust-top, back-arc) sedimentary basins, characterised by different subsidence rates and sedimentary processes (Cipollari et al. 1999). In SW Anatolia, the contractional- and extension-related basins were developed as a consequence of the Tauride Orogeny associated with the overall convergence of the African-Eurasian plates during the Neogene to the Quaternary (Sözbilir 2005; Alçiçek and Ten Veen 2008; Ten Veen et al. 2009).

The western Taurides in SW Anatolia constitutes the eastern extension of the Alpine orogeny and correlates with the Hellenides of Greece (Poisson 1984, Özgül and Arpat 1973, Bernoulli et al. 1974). They are subdivided into three main isopic zones: the Beydağları Autochthon, Lycian Nappes and Antalya Complex (Özgül 1976, 1984; Fig. 1). On a regional scale, these tectonic units are attributed to different stages of the Neotethyan closure that is involved in the genesis and emplacement of large-scale carbonate platform units and ophiolitic nappes since the late Mesozoic (de Graciansky 1972; Collins and Robertson 1997, 1998). The Beydağları Autochthon forms a broad north-south trending anticlinorium, contains Liassic to middle Miocene platform carbonates tectonically underlying the Lycian and Antalya nappes emplaced at its western and eastern flanks, respectively (Waldron 1981; Hayward and Robertson 1982; Collins and Robertson 1999). The Lycian Nappes correspond to a segment of the orogenic belt that originated in the northern Neotethys and comprised composite allochthonous thrust sheets transported over the Beydağları platform from the Late Cretaceous to the middle Miocene (Hayward and Robertson 1982; Robertson et al. 2003; Collins and Robertson 2003). On the other hand, the Antalya Complex possibly originated from the southern Neotethyan domain and was emplaced on the eastern flank of the Beydağları platform by the Late Cretaceous to Neogene and consists of allochthonous Mesozoic and older rocks (Waldron 1981; Woodcock and Robertson 1982; Poisson et al. 2003; Koç et al. 2016).

The Lycian nappe stacks are covered, unconformably, by alluvial redbeds that are, in turn, overlain by upper Burdigalian shallow-marine reefal limestones (Altınl1 1955; Becker-Platen 1970; Şenel et al. 1989; Hakyemez and Örçen 1982; Hakyemez 1989; Şenel 1997a; İslamoğlu et al. 2005; Alçiçek and Ten Veen 2008; Özcan et al. 2009; Akdeniz 2011a, b; Büyükmeriç 2017). Further to the southeast, the nappe front is eventually overlain by Serravalian shallow marine clastics (Hayward 1984). The supra-allochthonous units are considered to be deposits of a piggy-back basin, transported atop southeastward migrating nappes during the middle Miocene (Alçiçek and Ten Veen 2008; Ten Veen et al. 2009). The final movement of the nappes was followed by regional uplift corresponding to a non-depositional period (Alçiçek et al. 2018) that lasted c. 7 myr. This phase took place under NW-SE directed extension, parallel to the transport direction of the nappes and resulted in an array of NE-SW striking graben-type depressions including Çal, Baklan, Acıgöl, Burdur, Çameli, Eșen and Beyağaç basins (Ten Veen 2004; Alçiçek et al. 2005, 2006; Alçiçek 2007; Ten Veen et al. 2009; Alçiçek et al. 2013a). The tectono-sedimentary development of these basins is relatively uniform in the sense that all basins comprise a tripartite basin-fill that consists of an association of alluvial fan, fluvial and lacustrine facies from proximal to basinal areas. Faunal evidence from the stratigraphic record of each basin indicates coeval terrestrial deposition through the early Turolian to the Gelasian.

\section{Comparative basin stratigraphy}

The first lithostratigraphical description and subdivision of SW Anatolian terrestrial successions were made by BeckerPlaten (1970), who proposed a lithostratigraphic Standard Profile for regionally correlative, discernible sedimentary units comprising Yatağan and Milet beds restricted to the Lycian hinterland. In this area, sedimentation is represented by a coeval tripartite sequence ranging from alluvial fan, fluvial and lacustrine deposits that laterally and vertically grade into each other. These units are collectively considered as 'neoautochthonous' deposits and lithostratigraphically designated as the Çameli Formation by the Turkish Petroleum Corporation (TPAO) (Erakman et al. 1982a, b; Meșhur and Akpınar 1984; Erakman and Alkan 1986) and the Mineral Research and Exploration Directorate (MTA) (Şenel et al. 1989; Konak and Șenel 2002) and reiterated by ensuing studies since then.

A first attempt incorporating the faunal evidence to strengthen both correlations and palaeoenvironmental reconstructions of the SW Anatolian basins was undertaken by Alçiçek (2010). Although that study was largely based on Saraç (2003), a scientific report with many preliminary fossil identifications, it did manage to produce a general tectono-stratigraphic framework of the region recognising three pulses of crustal extension resulted in graben-type basin formation as earlier proposed by Alçiçek (2001), Alçiçek et al. (2005) and Alçiçek (2007). Since then, biostratigraphical information on the area has increased tremendously. In addition to recent biostratigraphical studies (e.g. Van den Hoek Ostende et al. 2015a, b), newly discovered localities, which are currently being studied, as well as literature on the faunal evidence (e.g. Saraç 2003) that mostly had gone unnoticed, have contributed to a more accurate definition of the timing of the major changes in the sedimentation mode in the region and the accompanying environmental changes. As part of the work is still in progress, we can anticipate further advances in the reconstruction of the late Neogene and Quaternary history of SW Anatolia. On the other hand, during that time interval, only very few palynological investigations of this region and period have been published. A possible reason for this is the presence of sediments that do not favour palynomorph 


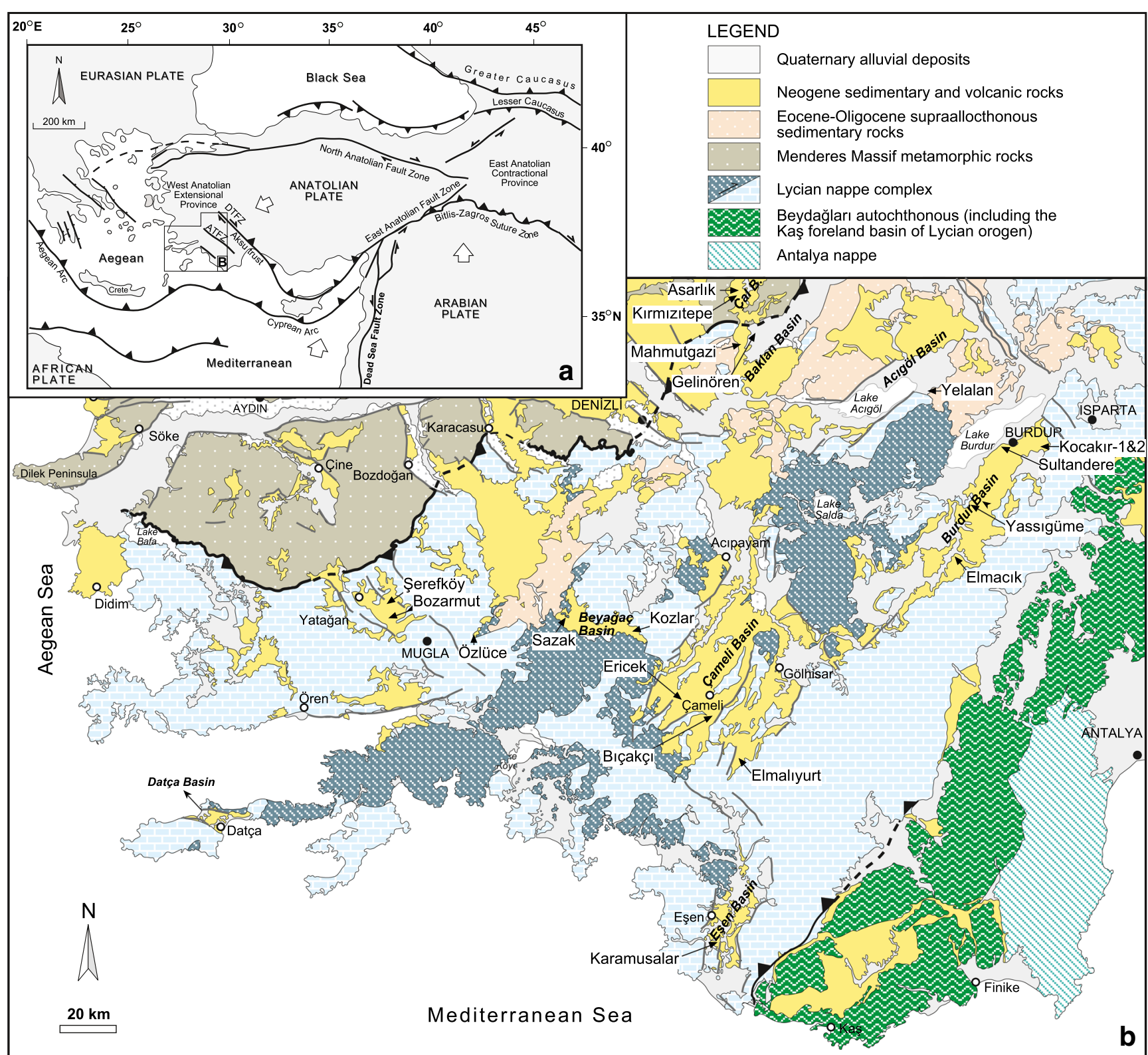

Fig. 1 a Tectonic map of the Aegean and Anatolia region showing the major tectonic structures (Bozkurt 2003; Alçiçek et al. 2013a; Kaymakç1 et al. 2018); DTFZ, Dinar Transfer Fault Zone; ATFZ, Acıpayam Transfer Fault Zone; b Overview of the prominent extensional basins of

preservation (e.g. oxidised or calcium carbonate or gypsum-rich sediments) discouraging a regular check for palynomorphs. Furthermore, the "Pollen Bilder" concept of Benda (1971) has been shown to be obsolete. For instance Fagus, Cedrus and Ilex defined the latest Miocene and early Pliocene pollen zone ('Yeni Eskihisar Pollen Bild') of Benda (1971), while several palynological investigations of SW Anatolia documented these taxa from older Miocene deposits (Biltekin et al. 2015; Supplemental Material 2 in Bouchal in press, this issue). Here, we synthesise existing palaeontological, sedimentological and various chronostratigraphic data with new observations on the pre-existing and new mammal fossil locations from the Lycian southwestern Anatolia (based on Konak 2002, Konak and Senel 2002, Senel 2002, Turan 2002). The fossil localities discussed in this study are indicated. See Figs. 2 and 3 for the stratigraphic position of the fossil sites and the ranges of the various taxa. Table 1 summarizes the contents

orogen-top basins to (re)define the stratigraphic framework and constrain the timing of major palaeo-environmental transitions in such key Neogene basins of SW Anatolia.

\section{The Çal Basin}

The Çal Basin resides on the Lycian Nappes (Konak et al. 1986; Konak 2002). The basin-fill consists of two sequences, which are separated by an angular unconformity. These sequences comprise sediments deposited in alluvial fan, fluvial and palustrine environments. The alluvial fan association constitutes the proximal and basal part of the basin-fill, which 
thickens towards the basin boundary faults and shows a basinward fining trend.

From the Asarlık locality, Kaya et al. (2008) and Alçiçek et al. (2012) reported Giraffidae (Samotherium sp., Palaeotragus sp.), Bovidae (Gazella sp., Palaeoreas cf. elegans), Suidae (Microstonyx sp.), Chalicotheriidae (Ancylotherium pentelici) and Equidae (Hipparion sp.), indicating middle Turolian age (MN12) (Table 1; Fig. 2). The alluvial fan deposits gradually pass upward into fluvial and palustrine facies associations that contain the freshwater molluscs of Bithynia and Dreissena and the ostracods Cyprideis and Ilyocypris. The lower unit is unconformably overlain by alluvial floodplain deposits with a distinct palaeosol horizon at the top. This unit is restricted to the central part of the basin and forms an extensive plateau preserved as hanging terraces. The floodplain deposits near Kirmizitepe locality yielded Equidae (Equus sp.) and are attributed to be of Biharian age (Alçiçek et al. 2012) (Table 1; Fig. 2).

\section{The Burdur Basin}

The Burdur Basin (Fig. 1) resides on Mesozoic carbonate and ophiolite units of the Lycian Nappes and Eocene-Oligocene supra-allocthonous sedimentary units (Șenel 1997a, 2002; Konak and Şenel 2002). The basin succession is composed of alluvial fan to fluvial and shallow to deep lacustrine facies associated with volcanic intercalations (Karaman 1986; Price and Scott 1989; Alçiçek et al. 2013a; Demirel and Mayda 2014; Alçiçek et al. 2017a). Price (1989) reported some giraffid remains from the basal part of the basin-fill, representing the oldest fossil record reported in the basin (Fig. 2). The morphology of the astragalus of this taxon is notably different from Plio-Pleistocene forms, suggesting a Turolian age for the specimen. Saraç (2003) also listed Dipoides sp., an extinct beaver genus, from the BurdurAkören-2 locality that belongs to the late Miocene/early Pliocene Anatolian faunas (MN12-MN14).

Recently, new macro-mammal remains were discovered in marsh/swamp deposits that stratigraphically lie in between the fluvial and lacustrine deposits of the basin succession. The micro- and macro-mammal fossil contents from the Sultandere locality (Fig. 1) revealed that a diverse fauna implying a wide variety of habitats were present during the early Pliocene (MN14/15, Ruscinian). Among the fossil mammals, the medium-sized deer Croizetoceros (Mayda et al. 2017) and the antelope Gazellospira are typical taxa of the PlioPleistocene, whereas the primitive gerbil genus Pseudomeriones has its latest representative in the late Pliocene (MN15) locality of Çalta (Șen 1977, 1998; Sylvestrou and Kostopoulos 2007) (Fig. 2). In addition, Fischer in Tchihatcheff (1866) reported four species of fossil gastropods from the lacustrine deposits of the Burdur Basin, three of which are endemic to SW Anatolia. A recent magnetostratigraphic study (Özkaptan et al. 2018) assigns an age of 5.0-3.6 Ma for the base of the lacustrine succession in the basin. This age determination calibrates our recent finding of MN15 biota in the Sultandere locality underlying the lacustrine succession of the Burdur Basin (Table 1).

The uppermost part of the basin succession, which consists of fluvio-deltaic deposits, yielded a middle-late Villafranchian fauna from the localities of Elmacık, Yassıgüme and Kocakır (Alçiçek et al. 2013b, Alpagut et al. 2015, Demirel and Mayda 2014, Demirel et al. 2016, 2017; Table 1, Fig. 2) aligned along the SE margin of the basin. The Elmacik locality contains Proboscidea (Mammuthus meridionalis, Elephantidae indet.), Equidae (Equus stenonis/altidens, Equus sp.), Rhinocerotidae (Stephanorhinus cf. etruscus), Bovidae (Gazellospira torticornis, Leptobos etruscus, Eobison sp., Bovidae indet.), Cervidae (Eucladoceros sp., Cervidae indet.), Testudinidae (Testudo sp.) and avian remains (Alpagut et al. 2015). The Yassigüme locality (Demirel and Mayda 2014) contains Leptobos cf. etruscus, Gazellospira torticornis and Equus sp. indicating a late Villafranchian association, which was typical for western and southeastern European taxa. This assemblage suggests an early late Villafranchian $(\sim 1.5 \mathrm{Ma})$ age of the uppermost part of the basin succession. The new locality of Yassigüme provided two differently sized bovids and Equus. Pleistocene fossil bovid remains from Turkey are rare. The Yassigüme bovine Leptobos etruscus is the first occurrence of this species in Anatolia, expanding the known range of the species.

The Kocakır-1 locality contains Equus sp. and Paracamelus gigas (Alçiçek et al. 2013b). Kocakır-2 is stratigraphically comparable but is much richer in species than Kocakır-1. The tentative results of the initial survey of Kocakır-2 showed the presence of two equids of different size (Equus cf. altidens and Equus suessenbornensis), a small rhino (Stephanorhinus cf. hundsheimensis), a giant camel (Paracamelus gigas), a panther (the size of $P$. gombaszoegensis), a wolf-like dog (Canis arnensis), a hippo (Hippopotamus sp.) and a medium-sized bovid (Bovidae indet.) (Table 1). Overall, this fairly diverse fauna reflects an open habitat with a limited number of water bodies. The combination of Paracamelus, Equus and a medium-sized deer is typical for the middle-late Villafranchian associations of eastern Europe and western and central Asia (Alçiçek et al. 2013b; Kahlke et al. 2011).

Further to the south, a locality near the village of Hasanpaşa is situated in the uppermost part of the lacustrine unit. This site yielded Mammuthus cf. meridionalis and Gazella sp., indicating a late Pliocene-early Pleistocene age (3.0-2.0 Ma; MN17; middle Villafranchian, Sickenberg et al. 1975, Saraç 2003). A recent magnetostratigraphic study indicates $2.5 \mathrm{Ma}$ for the top of the succession (Özkaptan et al. 2018). This age determination calibrates late Villafranchian (MNQ19) biota from the Kocakır-1 (Alçiçek et al. 2013b) and Kocakır-2 and Yassigüme localities (Demirel and Mayda 2014) overlying the lacustrine succession of the Burdur Basin (Table 1). 
Table 1 Biochronological and geochronological data from the Neogene marine and terrestrial sedimentary units exposed in the array of Lycian orogen-top basins of SW Anatolia (marine biota: Becker-Platen 1970, Hakyemez and Örçen 1982, Meșhur and Akpınar 1984, Konak et al. 1986, Șenel et al. 1989, Șenel 1997a, b, İslamoğlu et al. 2005, Șenel 2010, Akdeniz 2011a, b, Büyükmeriç 2017; terrestrial biota: Atalay 1980, Karaman 1986, Göktaș et al. 1989, Price 1989, Price and Scott 1989, 1991, Sun 1990, Kaya 1993, Tuna 1999, Alçiçek 2001, Saraç 2003, Alçiçek 2007, Șenel 2010, Akdeniz 2011a, b, Kaya et al. 2012, Van den Hoek Ostende et al. 2015a, b, Jiménez-Moreno et al. 2015,
Neubauer et al. 2015, Alçiçek et al. 2017a, b, Sickenberg and Tobien 1971, Sickenberg et al. 1975, Alçiçek et al. 2005, Wesselingh and Alçiçek 2010, Alçiçek et al. 2012, Alçiçek et al. 2013a, b, Alçiçek and Alçiçek 2014, Demirel and Mayda 2014, Pickford 2016, Geraads 2017 , Demirel et al. 2016, 2017, Darbaș 2017). Note that the terrestrial biota are well in accordance with the geochronological constraints provided by Paton (1992), Westaway et al. (2005), Sulpizio et al. (2013), Lefevre et al. (1983), Platevoet et al. (2008), Elitez et al. (2017) Demory et al. (2018), Özkaptan et al. (2018), Athanassas et al. (2018) and Çoban et al. (2019). See text for explanation

\begin{tabular}{|c|c|c|}
\hline Unit & Fossil assemblages & Age \\
\hline $\begin{array}{l}\text { Alluvial fan } \\
\text { floodplain }\end{array}$ & $\begin{array}{l}\text { Çal-Kırmızıtepe: Equus hydruntinus (Alçiçek et al. 2012) } \\
\text { Acıgöl-Yelalan: Equus hydruntinus (Alçicek et al. 2013a, b) } \\
\text { Baklan-Gelinören: Meriones sp., Microtus sp. } \\
\text { Baklan-Așağıdağdere: Apodemus sp. (Alçiçek et al. 2013a) } \\
\text { Baklan-Așağıseyit: Monodacna imrei (Wesselingh and Alçiçek 2010), Euxinipyrgula sp. (Büyükmeriç and } \\
\text { Wesselingh 2018), Theodoxus bukowskii, Valvata cristata, Valvata piscinalis, Viviparus sp., Bithynia } \\
\text { pseudemmericia, Hydrobiidae indet., Radix sp., Stagnicola palustris, Gyraulus crista, Gyraulus cf. euphraticus, } \\
\text { Planorbarius corneus, Planorbis cf. carinatus, Segmentina nitida } \\
\text { Acıgöl Basin: } 3760 \text { BP (Sulpizio et al. 2013, Athanassas et al. 2018), } 2.4 \mathrm{Ma} \text { (Demory et al. 2018) } \\
\text { Burdur Basin: } 1.50 \pm 0.18 ; 1.38 \pm 0.13 \mathrm{Ma} \text { (Nemec et al. 1998), } 313 \pm 64-268 \pm 43 \mathrm{ka} \text {. (Çoban et al. 2019), } 115 \pm 3 \\
\text { to } 24 \pm 2 \mathrm{Ka}, 62 \pm 2-2.77 \pm 0.006 \mathrm{Ka} \text { (Platevoet et al. 2008), } 14.1 \pm 0.5-12.9 \pm 0.4 \mathrm{Ka} \\
\text { (Schmitt et al. 2014), } 13.4 \pm 0.3 \mathrm{Ka} \text { (Guillou et al. 2017) }\end{array}$ & $\begin{array}{c}\text { Toringian-early } \\
\text { Biharian }\end{array}$ \\
\hline
\end{tabular}

Angular unconformity

Anastomosing fluvial

Lacustrine
Çameli-Bıçakçı: Sus strozzii, Mimomys pliocaenicus, Mimomys ex gr. M. tornensis, Pitymimomys pitymyoides, Borsodia ex gr. newtoni-arankoides, Kalymnomys sp., Clethrionomys kretzoii, Cricetus sp., Mesocricetus aff. primitivus, Cricetulus aff. migratorius, Pliospalax sp., Apodemus cf. flavicollis, A. atavus, Pliospalax sp., Beremendia sp., Soricinae indet.; Bithynia leachii, Galba truncatula, Lymnaea stagnalis, Radix sp., Stagnicola sp., Anisus spirorbis, Gyraulus crista, Gyraulus piscinarum, Planorbis planorbis, Segmentina nitida, Oxyloma cf. elegans, Vallonia pulchella, Vertigo antivertigo, Imparietula brevior, Pisidium sp. 1, Pisidium sp. 2 (Van den Hoek Ostende et al. 2015a, Alçiçek et al. 2017a).

Burdur Kocakır-1: Equus sp., Paracamelus gigas, Cervidae indet. (Alçiçek et al. 2013a, b; Demirel et al. 2016, 2017).

Burdur Kocakır-2: Equus cf. altidens, Equus suessenbornensis, Stephanorhinus cf. hundsheimensis, Paracamelus gigas, Bovidae indet., Hippopotamus sp., Panthera ex gr. gombaszoegensis, Canis arnensis (Demirel et al. 2016, 2017).

Burdur Elmacık: Mammuthus meridionalis, Elephantidae indet., Equus stenonis/altidens, Equus sp., Stephanorhinus cf. etruscus, Gazellospira torticornis, Leptobos etruscus, Eobison sp., Bovidae indet., Eucladoceros sp., Cervidae indet., Testudo sp. (Alpagut et al. 2015).

Burdur Yassigüme: Equus sp., Gazellospira torticornis, Leptobos cf. etruscus (Demirel and Mayda 2014).

Burdur-Hasanpaşa: Mammuthus meridionalis, Gazella sp. (Saraç 2003)

Burdur Basin: 2.5 Ma (Özkaptan et al. 2018).

Çameli Basin: Corymbina elegans (Spratt and Forbes 1847), ?Staja cibyratica, S. anatolica (Willmann 1982), Lymnaea, Radix, Lithoglyphus, Pyrgula (Becker-Platen 1970), Melanopsis narzolina, Pseudamnicola kochi (= Tanousia adnata), P. margarita, P. margarita nuda (Alçiçek et al. 2005), Ostracoda: Amplocypris marginata, Candona sp., C. sieberi nodosa, C. exigua, Darwinula cylindrica, Eucypris sp., Metacypris sp. (Becker-Platen 1970), Cyprideis pannonica, Candona parallela pannonica, Heterocypris salina, Ilyocypris sp., Eucypris sp. (Darbas 2017).

Burdur Basin: Candona (Candona) burdurensis, Candona (Candona) devexa, Candona (Candona) sp., Hyocypris gibba, Heterocypris salina salina, Heterocypris salina barneri, Ilyocypris bradyi, Ilyocypris gibba, Ilyocypris sp., Limmocythere spinosa, (Tunoğlu and Bayhan 1996), Valvata orientalis, Bithynia phrygica, "Hydrobia" sp., Planorbis fischeri (Fischer in Tchihatcheff 1866, Wenz 1919).

Eșen Basin: Corymbina elegans, ?Staja cibyratica (Spratt and Forbes 1847), Staja lycia (Oppenheim 1919), Ilyocypris cf. expansa, Pisidium sp., Tylopoma avellana, Planorbidae indet. (Colin 1962), Bithynia cf. pilari, Corymbina aff. rhodensis var. istridica, Ancylocypris sinuosa, Miocyprideis janoscheki, Candona filona, Candona extensa, Pontocypris balcanica, Cyprideis aff. littoralis, Ilyocypris cf. iners, Candona ex aff. neglecta, Candona granulosa, Ilyocpris sp., Hemicythere convexa, Candona albicans pannonica, Eucypris sp., Cyprideis heterostigma, Candona aff. balatonica, Hemicythere convexa, Candona aff. albicans, Cyprinotus congener, Limnocythere sp., Tyrrhenocythere sp. (Becker-Platen 1970), Acer aff. trilobatum, Acer angustilabum (Senel 1997b, c), Candona (Candona) xanthica, Candona (Candona) metohica, Candona (Candona) cabrati, Cypridopsis sp., Ilyocypris bradyi, Candona (Caspiocypris) sp.

Candona (Candona) bimucronata, Limnocythere sp., Ilyocypris bradyi, Candona (Metacandona) cf. dasherahi, Candona (Fabaeformiscandona) cf. krstici, Candona (Pontoniella) sp., Zonocypris cf. membrana, Cyprideis torosa (Alçiçek 2007).
Latest Villanyian

Late Pliocene 
Table 1 (continued)

\begin{tabular}{|c|c|c|}
\hline Unit & Fossil assemblages & Age \\
\hline $\begin{array}{l}\text { Anastomosing } \\
\text { fluvial }\end{array}$ & $\begin{array}{l}\text { Çameli-Ericek: Cricetulus sp., Apodemus cf. dominans, Orientalomys cf. similis, Mimomys occitanus, Muscardinus } \\
\text { sp., Asoriculus sp., Rhagapodemus primaevus, Bithynia sp., Pseudamnicola sp., Hydrobia s.l. sp., Valvata aff. } \\
\text { macrostoma, Galba sp., Vertigo sp., Gyraulus sp., Cyprininae indet., Capoeta sp., Capoeta cf. damascina or C. } \\
\text { cf. sieboldi, Carassius, Leuciscinae, ?Squalius sp., Tincinae indet., Tinca sp., Barbus sp., Cobitidae indet., } \\
\text { Gobiidae indet., ?Palaeobatrachidae indet., Anura indet., Colubridae indet. (Serpentes), Colubridae indet. or } \\
\text { Elapidae indet. (Van den Hoek Ostende et al. 2015a). } \\
\text { Baklan-Gelinören: Pseudomeriones tchaltaensis (Wesselingh and Alçiçek 2010). } \\
\text { Eşen -Karaboynuz: Onychodens sp., Mitradens sp., Tinca sp. (Alçiçek 2007). } \\
\text { Acigöl-Bademli: Dolomy sp., Apodemus sp. Soricid indet. (?Asoriculus) (Alçiçek et al. 2013a). } \\
\text { Burdur-Sultandere: Croizetoceros cf. romanus, Gazellospira sp. (Mayda et al. 2017). } \\
\text { Yatağan-Bozarmut: Hipparion sp., Arvicolinae indet. (Saraç 2003). } \\
\text { Burdur Basin: 5.0-3.6 Ma (Özkaptan et al. 2018). }\end{array}$ & Late Ruscinian \\
\hline
\end{tabular}

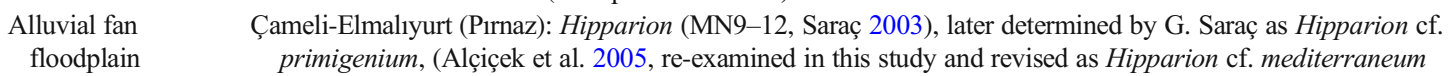

Early Turolian MN11-12)

Eșen-Karamusalar: Palaeotragus rouneii (MN9-12, Alçiçek 2007). The specimen of Palaeotragus rouneii re-examined with support of new findings of Gazella sp., Hipparion sp., Cervidae indet. assigning MN11-12.

Burdur-Kemer: Giraffidae indet. (Price 1989). Burdur-Akören-2: Dipoides sp. (Saraç 2003).

Çal-Asarlık: Samotherium sp., Palaeotragus sp., Gazella sp., Palaeoreas cf. elegans, Hippopotamodon sp., Ancylotherium pentelici, Hipparion sp. (Alçiçek et al. 2012).

Mahmutgazi: Adcrocuta eximia, Protictitherium crassum, Machairodus aphanistus, Indarctos atticus, Chilotherium schlosseri, Ceratotherium neumayri, Ancylotherium pentelicum, Cremohipparion matthewi, Palaeoryx pallasi, Plesiaddax inundatus, Tragoportax amalthea, Samotherium major, Hippopotamodon erymanthius, Orycteropus sp. and Choerolophodon pentelici (Sickenberg and Tobien 1971, Sickenberg et al. 1975; Pickford 2016; Geraads 2017).

Beyağaç-Sazak: Adcrocuta eximia, Cremohipparion matthewi, Ceratotherium neumayri, Gazella deperdita, Protoryx carolinae, Tragoportax almathea, Helladotherium duvernoyi (Kaya 1993; Tuna 1999; Koufos et al. 2018).

Beyağaç-Kozlar: Hipparion sp., Ceratotherium sp.

Özlüce: Dinocrocuta gigantea, Choerolophodon anatolicum, Hipparion sp. (I), Hipparion sp. (II), Ceratotherium neumayri, Chilotherium cf. kiliasi, Chilotherium nov. sp., Sporadotragus nov. sp., Skoufotragus sp., Hippopotamodon sp. (Alpagut et al. 2014).

Yatağan-Șerefköy 2: Machairodus giganteus, Felis attica, Paramachairodus orientalis, Adcrocuta eximia, ?Ursavus sp., Parataxidea cf. maraghana, Pliohyrax graecus, Ceratotherium neumayri, Dihoplus sp., Ancylotherium pentelicum, "Hipparion" sp. type 1, "Hipparion" sp. type 2, Hippotherium brachypus, Hippopotamodon major, Palaeotragus rouenii, Samotherium sp., Orycteropus gaudryi, Choerolophodon pentelici, Deinotherium sp., Gazella cf. capricornis, Palaeoryx pallasi, Sporadotragus parvidens, Skoufotragus cf. S. schlosseri, Urmiatherium rugosifrons, ?Sinotragus sp. (Kaya et al. 2012, Kostopoulos and Karakütük 2015).

Kemiklitepe (A/B): Amphimachairodus giganteus, Adcrocuta eximia, Hyaenictitherium wongii, Lycyaena sp., Agriotherium sp., Pliohyrax graecus, Orycteropus gaudryi, Ancylotherium pentelicum, Cremohipparion matthewi, Hipparion mediterraneum, Ceratotherium neumayri, Gazella sp., Pachytragus laticeps, Palaeotragus pavlowae, Samotherium major, Choerolophodon pentelicus, Hystrix primigenia, Pseudomeriones sp. (Șen et al. 1994).

Kemiklitepe (D): Machairodus aphanistus, Hipparion mediterraneum, Chilotherium sp., Ceratotherium neumayri, Criotherium argalioides, Gazella sp., Mesembriacerus melentisi, Palaeoreas lindermayeri, Palaeoreas elegans, Palaeotragus pavlowae, Pliohyrax graecus, Choerolophodon pentelicus (Șen et al. 1994).

Karabeyli: Hipparion sp., Struthio sp., Ictitherium viverrinum, Hipparion brachypus, Hipparion sp. (II), Paleotragus sp., Gazella capricornis, Protoryx sp., Palaeoryx pallasi, Hippopotamodon major, Samotherium boissieri, Choerolophodon pentelici (Seyitoğlu et al. 2009).

Burdur Basin: $4.77 \pm 0.25$ to $4.07 \pm 0.20 \mathrm{Ma}$ (Lefevre et al. 1983), $4.6 \pm 0.2 \mathrm{Ma}$ (Price 1989).

Çameli Basin: 6.9 Ma (Elitez et al. 2017).

Denizli Basin (SE margin): $6.52 \pm 0.33$ to $4.59 \pm 0.57 \mathrm{Ma}$ (Paton 1992), $6.71 \pm 0.2 \mathrm{Ma}$ (Westaway et al. 2005).

\section{No deposition, c. 7 myr comprising entire Langhian and early Tortonian}

Reef Limestone (brackish-shallow marine)
Gastropoda: Turritella turris, Tenagodus cf. terebellus, Oligodia bicarinata, Phalium (Phalium) cypraeiformis, Melongena cf. cornuta, Conus (Conospirus) dujardini, Conus (Lithoconus) mercati.

Bivalvia: Hyotissa hyotis, Codakia cf. leonina, Ostrea lamellosa, Venus (Antigona) burdigalensis producta, Pecten subarcuatus styriacus, Lutraria $\mathrm{cf}$. sanna, Pelecyora (Cordiopsis) islandicoides, Venus (Antigona) burdigalensis producta. Ostracoda: Aurila soummamensis, Neonesidea corpulenta, Xestoleberis glabrences, Hermanites aff. haidingeri minör, Cytherura cf. gibba, Cytheretta aff. ramosa sublaevis, Hemicyprideis rhanana, Krithe papillosa, Neomonoceratina helvetica, Neonesidea corpulenta, Krinta papillosa, Bairdia sabdeltoidea, Cytherella vulgata, Paracypris polita, Benthic foraminifera: Miogypsina intermedia, Miogypsina cf. irregularis, Neoalveolina melo, Operculina complanata, Ammonia becarii, Quinqueloculina sp., Amphistegina sp., Elphidium sp., Rotaliidae, Miliolidae. Scleractinian corals: Heliastraea cf. mellahica, Stylophora cf. raristella. Tabellastraea sp., Favia sp. Algae: Lithophyllia sp., Lithothamnium sp., Melobesia sp. Autochthonous and allochthonous basement units (Mesozoic-Miocene)
Late Burdigalian

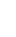




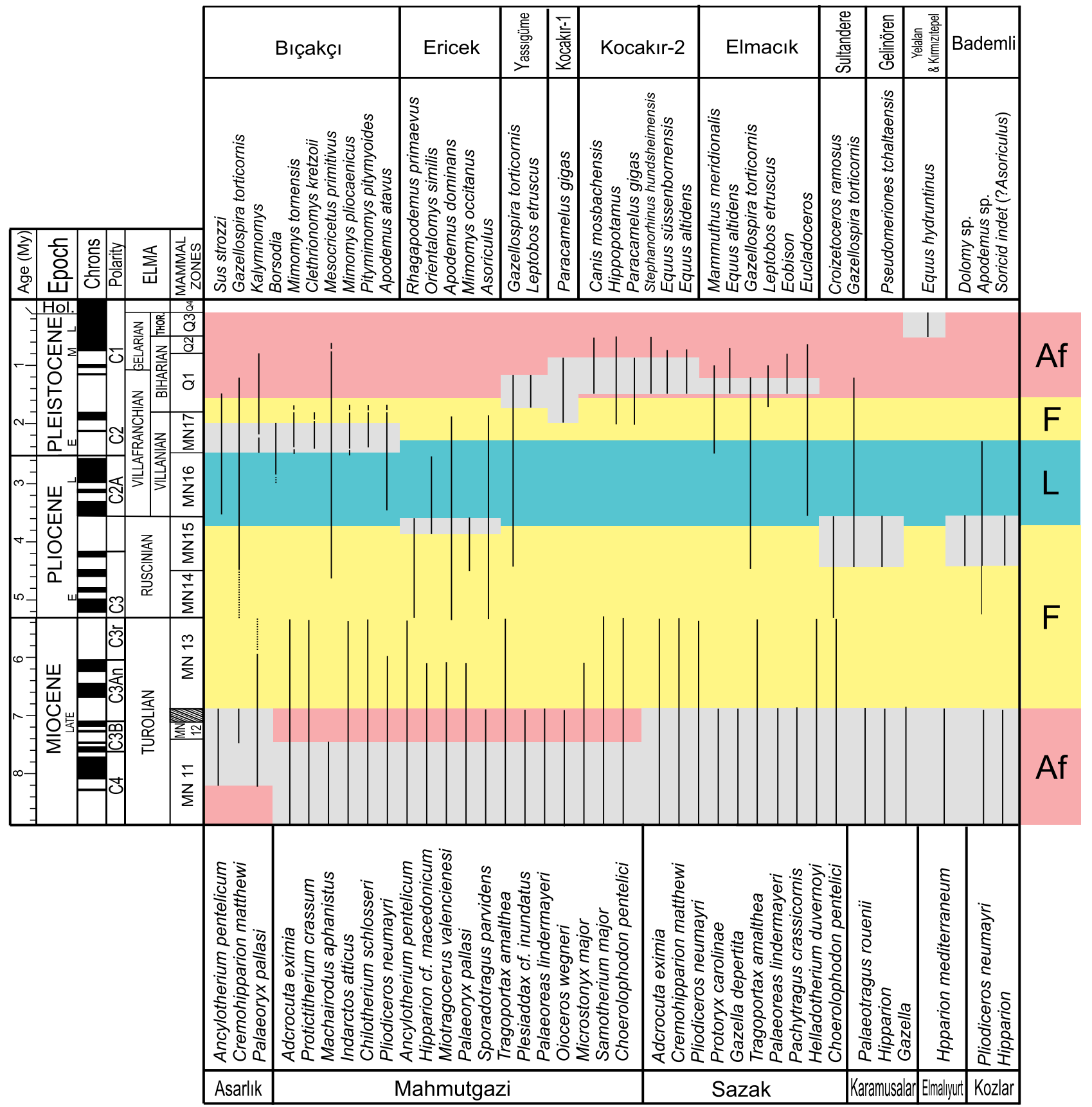

Fig. 2 Biostratigraphic range and the biochronologic interpretation of Turolian and Plio-Pleistocene taxa from the SW Anatolian terrestrial basins: Biçakçı (Alçiçek et al. 2005, 2017a, Van den Hoek Ostende et al. 2015a), Ericek (Alçiçek et al. 2005, Van den Hoek Ostende et al. 2015b), Yassigüme (Demirel and Mayda 2014), Kocakır-1 (Alçiçek et al. 2013b), Kocakır-2 (Demirel et al. 2016, 2017), Elmacık (Alpagut et al. 2015), Sultandere (Mayda et al. 2017), Gelinören (Wesseling and Alçiçek 2010), Yelalan (Alçiçek et al. 2013b), Kırmızıtepe (Alçiçek et al. 2012b), Bademli (Alçiçek et al. 2013a), Asarlık (Alçiçek et al. 2012),

Mahmutgazi (Sickenberg and Tobien 1971, Sickenberg et al. 1975, Saraç 2003, Geraads 2017, Pickford 2016), Sazak (Saraç 2003, Oruç 2009, Tuna 1999, Kaya 1993), Karamusalar (Alçiçek 2007, this study), Elmaliyurt and Kozlar (this study). The chronostratigraphic stages are based on Hilgen et al. (2012). Colour patterns with codes correspond to the facies associations of individual depositional environments (Af, alluvial fan; F, fluvial; L, lacustrine). See Figs. 1, 3 and Table 1 for the locations and stratigraphic positions of the fossil sites

In the Gölcük volcanic province, c. $20 \mathrm{~km}$ to the NE of the basin, the basin succession interfingers with volcaniclastics dating to $4.77 \pm 0.25$ to $4.07 \pm 0.20 \mathrm{Ma}$

(Lefevre et al. 1983). Price (1989) undertook K-Ar dating from tephra at the centrally placed Gölcük Maar, which provided an age of $4.6 \pm 0.2 \mathrm{Ma}$. The volcanic intrusions 
and lava flows overlie Miocene deposits and interfinger with the basin-fill. The middle parts of the volcanics were assumed to be of late Pliocene age based on the tephra interlayers of that age in the adjacent Burdur graben (Nemec et al. 1998). By using K-Ar age determination from tephra interlayers, Nemec et al. (1998) showed that the explosive activity of the Gölcük volcano continued until the early Pleistocene with the youngest activity in historical times at $1.50 \pm 0.18$ and $1.38 \pm 0.13 \mathrm{Ma}$.

\section{The Baklan Basin}

The Baklan Basin developed on the Mesozoic sequence of the Lycian Nappes (Sözbilir 2005, Konak and Șenel 2002, Alçiçek et al. 2013a; Fig. 1). The basin-fill consists of alluvial fan to fluvial and lacustrine deposits. The base of the sequence was dated as early Turolian based on large mammal fossils from the Mahmutgazi locality (Sickenberg and Tobien 1971; Sickenberg et al. 1975; Pickford 2016; Geraads 2017). The locality includes three main fossil sites, which comprise a faunal assemblage including the following species: Adcrocuta eximia, Protictitherium crassum, Machairodus aphanistus, Indarctos atticus, Chilotherium schlosseri, Ceratotherium neumayri, Ancylotherium pentelicum, Cremohipparion matthewi, Palaeoryx pallasi, Plesiaddax inundates, Tragoportax amalthea, Samotherium major, Hippopotamodon erymanthius, Orycteropus sp. and Choerolophodon pentelici. This diverse fauna resembles the late Miocene assemblage from the Greco-Iranian bioprovince, and this locality can be assigned to late MN11 (Table 1; Fig. 2). A diverse mollusc assemblage has been collected from the lacustrine deposits. While most of the gastropods are also known from modern freshwater environments, the hydrobiid Euxinipyrgula and the Lymnocardiinae bivalve Monodacna in the region indicate affinities to the Pontocaspian fauna (Wesselingh and Alçiçek 2010; Büyükmeriç and Wesselingh 2018). The finding of Pseudomeriones tchaltaensis reported by Wesselingh and Alçiçek (2010) suggested a Ruscinian (MN15/16) age. Reidentification of this find to Meriones sp. and the find of Microtus sp., however, showed that the deposits are in fact of Biharian age.

\section{The Acıgöl Basin}

The Acıgöl Basin resides on the Mesozoic basement composed of allochthonous rocks of limestones and ophiolitic rocks of the Lycian Nappes, overlying Oligocene marine to continental units (Konak et al. 1986, Senel 1997c, Konak and Senel 2002, Turan 2002, Sözbilir 2005; Fig. 1). The basin strikes NE-SW and is developed within a southeastward-tilted tectonic depression in which upper
Miocene alluvial fan and fluvial deposits including magnesite-rich lacustrine sediments were deposited at the base (Göktaş et al. 1989; Alçiçek 2009; Helvacı et al. 2013; Alçiçek et al. 2013a). During the Pliocene, progressive deepening of the basin provided accommodation space for the deposition of lacustrine units, which unconformably overlie the pre-Neogene basement. By the Pleistocene, coarse-grained alluvial fan deposits prograded over the lacustrine deposits. The only fossil mammal material is recorded in the alluvial fan deposits of the uppermost reach of the Acigöl basin-fill and represents a typical late Pleistocene element in the form of Equus hydruntinus (Alçiçek et al. 2013b).

\section{The Çameli Basin}

The Çameli Basin resides on the Lycian Nappes and constitutes NE-trending interconnected back-tilted block compartments associated with NW-dipping secondary normal faults (Fig. 1). The basin-fill was designated as the Çameli Formation by Erakman et al. (1982a, b) and Erakman and Alkan (1986) and comprises alluvial fan, fluvial and lacustrine deposits. Progressive angular unconformities are present within the proximal facies along the basin margins. The alluvial fan deposits occur in the lower and the upper parts of the basin-fill along the basin margin and grade laterally and vertically into the fluvial deposits. The fluvial deposits also grade laterally and vertically into lacustrine facies that are restricted to the central and the upper part of the sequence. In the basin centre, these tripartite facies grade into each other and reach up to $500 \mathrm{~m}$ in thickness. The age of the basin-fill was determined to be Turolian to Villanyian based on the mammal fauna and radiometric dating (Șenel 1997a, b, c; Saraç 2003; Alçiçek et al. 2005; Van den Hoek Ostende et al. 2015a, 2015b; Elitez et al. 2017). The biostratigraphical studies by Van den Hoek Ostende et al. (2015a, b) have contributed to accurately define the timing of major changes in the sedimentation mode within the basin.

The vertebrate fauna of coal-bearing deposits in the Elmaliyurt (Prrnaz) locality on the SE margin of the basin contains an upper dentition of a medium-sized hipparionine (Saraç 2003; Table 1). This mammal specimen was preliminarily identified by G. Saraç as the Vallesian species Hippotherium primigenium (Alçiçek 2001) and this identification was reiterated by Alçiçek et al. (2005). The characteristics of the $H$. primigenium group as defined by Bernor et al. (1996) are complex pre- and post-fossette enamel plications, maintaining deeply amplified plis and an incised hypoglyph accompanying the lingually flattened, labially rounded and more lingually placed protocone. Comparing the mean protoconal length and the plication count, the Elmaliyurt specimen differs from those of $H$. primigenium from Höwenegg 
(MN9; Vallesian) and Eppelsheim (MN9-10; Vallesian) by having a moderate enamel plication (15-20 plicae) with short-narrow plis, oval, relatively small protocone $(6-8 \mathrm{~mm})$ free from protoloph with weak and asymmetrical double pli caballin. Instead, the medium-sized Elmaliyurt hipparion is comparable with the Turolian forms of Bulgaria and Greece and especially those from the Anatolian faunas of SivasDüzyayla (MN11, early Turolian, Kaya and Forstén 1999), Uşak-Kemiklitepe A-B (MN11-12, early-middle Turolian, Koufos and Kostopoulos 1994), Muğla-Șerefköy (MN12; early Turolian, Kaya et al. 2012) and Özlüce (MN11, early Turolian, Alpagut et al. 2014). In particular, $H$. mediterraneum, which is well represented in middle Turolian (MN12) localities from Greece (Pikermi and Perivolaki), Bulgaria (Kalimantsi and Hadjidimovo) and Turkey (Kemiklitepe A-B and Düzyayla), closely resembles the Elmaliyurt hipparion in size and morphology. In view of the existing material, we classify the Elmalıyurt specimen as Hipparion cf. mediterraneum, noting that it certainly does not represent $H$. primigenium but rather resembles Turolian forms. Consequently, the Elmalıyurt locality in the lowermost part of the Çameli Basin succession is considered to be Turolian in age, in line with radiometric data provided by Elitez et al. (2017).

The lacustrine unit in the basin is confined by coal-bearing marsh-swamp deposits at the bottom and the top. At the base, the Ericek locality contains murine (Apodemus cf. dominans, Rhagapodemus cf. primaevus, Orientalomys cf. similis), arvicoline (Mimomys occitanus), cricetine (Cricetulus sp.), glirid (Muscardinus sp.) and shrew (Asoriculus sp.) species, which were assigned to late MN15, i.e. late Ruscinian (Van den Hoek Ostende et al. 2015a, Table 1; Fig. 2). Higher in the section, the unit grades from a shallow to a deep lake environment. The mollusc content, with Melanopsis, Staja, Pseudamnicola, Pyrgula, Tanousia, Lithoglyphus, Corymbina, Lymnaea and Radix (Becker-Platen 1970; Alçiçek et al. 2005), and the ostracods Cyprideis pannonica, Candona parallela pannonica, Heterocypris salina, Ilyocypris sp. and Eucypris sp. (Darbaş 2017) mark the transition from shallow to open lake environments. The uppermost part of the lacustrine succession grades again into coalbearing marsh-swamp deposits abounding in mammal remains including cricetines, arvicolines and murines as reported in the locality of Bıçakçı (MN17, late Villanyian; Alçiçek et al. 2005, Van den Hoek Ostende et al. 2015b, Alçiçek et al. 2017a; Table 1; Fig. 2). The molluscs of that interval, with Bithynia, Pisidium and abundant pulmonates, show modern affinities typical of a shallow, vegetated, lentic environment.

\section{The Eşen Basin}

The Eşen Basin, a NE-trending extensional graben, resides on the hinterland ramp-fold near the Lycian nappe front (Alçiçek
2007; Fig. 1). This terrestrial basin is highly comparable with the adjacent Çameli Basin, from which fossil mammals allow reliable stratigraphic comparisons with recognised extensional pulses (Alçiçek et al. 2005). The early basin-fill was described as comprising alluvial fan deposits including Palaeotragus rouneii (Artiodactyla, Giraffidae) (MN9-12, Vallesianmiddle Turolian, Karamusalar locality, Alçiçek 2007) and an ostracod fauna containing species of Hemicythere, Candona, Eucypris, Cyprideis and Pontocypris (Becker-Platen 1970). In the course of this study, new large mammal remains have been unearthed from the same locality reported by Alçiçek (2007). The newly collected material contains a small-sized bovid (Gazella sp.), a cervid (Cervidae indet.), an equid (Hipparion sp.) and a small-sized giraffid (Palaeotragus sp.), constraining the age to Turolian (MN11-12; Table 1, Fig. 2).

The alluvial fan deposits grade upward into fluvial and eventually shallow lacustrine deposits. Initial lacustrine deposition is represented by marsh-swamps containing freshwater ostracods and molluscs including Miocyprideis, Limnocythere, Candona, Ilyocypris, Cypridopsis, Cyprideis, Bithynia, Tylopoma, Staja, Corymbina and Psidium (Colin 1962; Becker-Platen 1970), as well as Cyprinidae remains belonging to the genera Onychodens, Mitradens and Tinca (Alçiçek 2007). Upward, the lacustrine deposits abound in mollusc, ostracod and fish assemblages representing a deeper lake environment (Table 1). Later, the deep lacustrine basin eventually shrank and was filled owing to renewed progradation of alluvial fan and fan-deltaic deposits derived from the basin margins.

\section{The Beyağaç Basin}

The Beyağaç Basin was first described by Becker-Platen (1970; there as 'Gebiet der Barz-Ebene') and its geological map has recently been compiled by Akdeniz (2011a); Fig. 3). The basin contains two distinct sedimentary units: the Yatağan beds at the base, comprising alluvial fan and fluvial deposits, and the Milet beds with lacustrine sediments at the top.

The basal Yatağan unit consists of alluvial fan and fluvial deposits, which thicken towards the basin boundary faults and show basinward thinning and fining trends. The Sazak locality, at the western basin margin, yielded the fossils of Cremohipparion matthewi, Ceratotherium neumayri, Helladotherium duvernoyi, Protoryx carolinae, Tragoportax amalthea, Gazella deperdita and Adcrocuta eximia, indicating a middle Turolian age (MN12; Schmidt-Kittler 1976, Kaya 1993, Tuna 1999, Koufos et al. 2018). The new Kozlar locality at the eastern basin margin was discovered during this study and is still under investigation but revealed equid (Hipparion) and rhinocerotid (Ceratotherium) material suggesting a middle Turolian age (MN12, Table 1; Fig. 2). Higher up in the sequence, the alluvial fan deposits gradually pass upwards into the fluvial facies association and are eventually overlain by the 


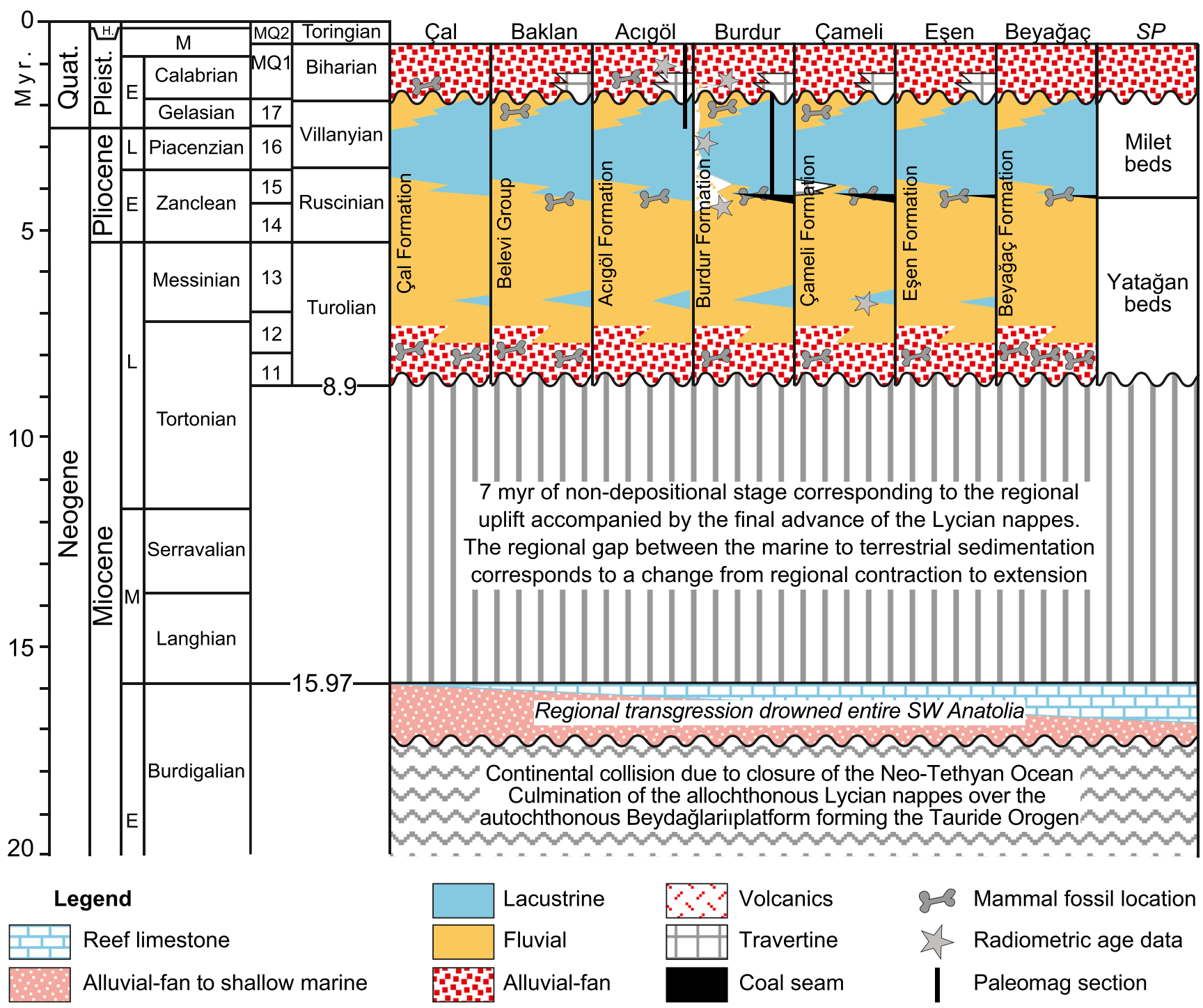

Fig. 3 Comparative stratigraphy for the synchronous extensional orogentop basins in SW Anatolia depicted by the biochronologic and geochronologic evidences: Çal (Alçiçek et al. 2012; Alçiçek and Alçiçek 2014), Baklan (Sickenberg and Tobien 1971; Sickenberg et al. 1975; Konak et al. 1986; Sun 1990; Sarac 2003; Westaway et al. 2005; Wesselingh and Alçiçek 2010; Alçiçek et al. 2013a; Pickford 2016; Geraads 2017), Acıgöl (Göktaș et al. 1989; Sulpizio et al. 2013; Alçiçek et al. 2013a, b; Athanassas et al. 2018; Demory et al. 2018), Burdur (Sickenberg and Tobien 1971; Lefevre et al. 1983; Karaman 1986; Price 1989; Price and Scott 1989; Price and Scott 1991; Saraç 2003; Platevoet et al. 2008; Alçiçek et al. 2013a, b; Demirel and Mayda 2014; Alçiçek et al. 2017b; Demirel et al. 2016, 2017; Özkaptan et al. 2018, Coban et al. 2019), Çameli (Becker-Platen 1970; Erakman et al. 1982a, b; Meșhur and Akpınar 1984; Erakman and Alkan 1986; Saraç 2003; Alçiçek et al. 2005; Akdeniz 2011a; Van den Hoek Ostende et al. 2015a, b; JiménezMoreno et al. 2015, 2016; Elitez et al. 2017; Alçiçek et al. 2017a), Eșen (Becker-Platen 1970; Alçiçek 2007) and Beyağaç (Atalay 1980; Kaya 1993; Tuna 1999; Akdeniz 2011b). The chronostratigraphic stages are based on Hilgen et al. (2012). The oldest age of these orogen-top basins in SW Anatolia is early Turolian. The marine transgression which was extant in the region during the late Burdigalian was followed by the final advance of Lycian Nappes and caused a regional uplift during the Langhian-Tortonian (c. 7 myr) elsewhere in SW Anatolia (BeckerPlaten 1970; Hakyemez and Örçen 1982; Meșhur and Akpınar 1984; Șenel et al. 1989; Hakyemez 1989; Sözbilir 2005; Alçiçek 2001; Konak and Senel 2002; İslamoğlu et al. 2005; Alçiçek and Ten Veen 2008; Senel 2010; Akdeniz 2011a, b; Büyükmeriç 2017; Alçiçek et al. 2018). The readers are referred to Alçiçek (2010), Alçiçek et al. (2013a), Alçiçek (2015), Alçiçek et al. (2017b) and Alçiçek et al. (2018) for further correlative stratigraphy of the SW Anatolian Neogene basins. For the geographic locations of these basins, see the geological maps by the MTA (The Geological Survey of Turkey, compiled by Konak and Şenel 2002, Konak 2002, Senel 2002, Turan 2002) and the compilation by Ten Veen et al. (2009). The tectonic information is compiled from Ten Veen et al. (2009), Jolivet et al. (2015), Över et al. (2010),Över et al. 2016a, b), Howell et al. (2017) and Kaymakçı et al. (2018). Note that the SW Anatolian terrestrial basins are strongly synchronic and compatible to the lithostratigraphic Standard Profile (SP) which was initially proposed for the lithostratigraphical subdivision of entire SW Anatolian Neogene formations by Becker-Platen (1970). See Fig. 1 for the location of the basins and Fig. 2 for the stratigraphic position of the fossil and the absolute age sites, Table 1 summarizes their content 
lacustrine Milet unit with a coal seam at the bottom. The basinfill is unconformably overlain by younger alluvial fan deposits.

\section{Discussion}

Regional crustal extension following the culmination of the Tauride orogeny gave rise to the development of terrestrial basins in SW Anatolia (Șengör and Yılmaz 1981; Robertson and Dixon 1984; Șengör et al. 1985; Zanchi et al. 1993; Ten Veen et al. 2009). A combination of detailed bio- and lithostratigraphy of the basin-fills underpins a well-constrained model for the basin evolution that is used here as a solid stratigraphic framework enabling the improved timing of tectonic events along the Lycian hinterland.

For the basins in the SW Anatolian Taurides, Alçiçek (2001) attempted to obtain a stratigraphic resolution that would enable an accurate definition for the duration of tectonic phases related to crustal deformation. Following that approach, Alçiçek et al. (2005) and Alçiçek (2007) described terrestrial orogen-top basins such as Çameli and Eşen and distinguished three distinct pulses of crustal extension that occurred in late Miocene, early Pliocene and early Pleistocene times, respectively. Spatio-temporal correlation of each individual basin-fill indicates a coeval deposition of tripartite facies associations: alluvial fan facies at the margin, fluvial and lacustrine facies in the centre.

The final nappe-related sedimentation in the region occurred during the early Miocene in piggy-back basins composed of terrestrial deposits, which were subsequently sealed by upper Burdigalian reefal limestones. This marine transgression was followed by regional uplift associated with local extension and formation of a NE-striking array of normalfault-bounded grabens of late Turolian-Villanyian age. The reef unit presently stands at maximally $1846-\mathrm{m}$ elevation attributed to the gravitationally isostatic (orogenic) rebound of the nappe stack (Alçiçek and Ten Veen 2008) following the slab break-off. These large-scale sequences are separated by a long-lasting (c. $7 \mathrm{myr}$ ) hiatus through the Langhian to the late Tortonian (late Orleanian to early Turolian) corresponding with a shift from compression to extension within the geodynamic context of orogenic culmination followed by a post-orogenic extension (Alçiçek et al. 2018).

The post-orogenic terrestrial basins collectively provide sedimentary and stratigraphic evidence indicating the synchronicity of the individual basin developments and related sedimentation as well as interconnections between these basins. The new age constraints presented here provide the means to place the basin development in a regional tectonic framework. Late Neogene and Quaternary tectonics of western Anatolia are characterised by crustal extension associated with the development of NE-SW fault-bounded basins. This extension has strongly influenced the basin configuration, changed the sedimentation mode and gave rise to several graben-type basins such as the Çal, Baklan, Acıgöl, Burdur, Çameli, Eșen and Beyağaç basins. Here, we synthesise the available data to develop a unified three-phase scenario of terrestrial basin sedimentation across the SW Anatolian region.

Phase I-Basin formation (late Tortonian)

The basal alluvial floodplain deposits of the SW Anatolian basins abound in large fossil mammal remains such as those found at the localities of Mahmutgazi in Baklan, Asarlık in Çal, Elmalıyurt (Pırnaz) in Çameli, Karamusalar in Eşen, Șerefköy in Yatağan, Sazak and Kozlar in Beyağaç, and Kemer in Burdur basins (Table 1, Fig. 2). The fossils found at these localities are typical examples of the so-called Greco-Iranian or subParatethyan province, also known as the Pikermi fauna (Kaya et al. 2012; Pickford 2016; Geraads 2017). The complex includes hipparionines, hornless rhinoceroses, giraffes and numerous representatives of antelopes and Bovinae. In Anatolia, this assemblage is co-occurring with open forested landscapes ranging from sclerophylous evergreen to mixed conifer and deciduous woodlands to open xerophyic terrains forming a mosaic of different plant associations (Jiménez-Moreno et al. 2007; Biltekin et al. 2015; Denk et al. 2018), indicative of relatively warm and humid climatic conditions in the late Tortonian. This humidity is supported by very low $\delta^{18} \mathrm{O}$ isotopic values of the floodplain carbonates $(-7.86$ to $-6.37 \%$ ) (Mahmutgazi locality) from the Baklan Basin lacustrine magnesites ( -6.50 to $4.06 \%$ ) from the Acıgöl Basin (Alçiçek 2009) and lacustrine carbonates from the Denizli Basin (Alçiçek et al. 2007). Around 5.9 Ma (late Turolian, late Messinian), an onset of drastic climatic change with greater aridity and continentality and cooler climate occurred in the eastern Mediterranean during the continued Africa-Europe convergence. This facilitated rapid faunal exchanges between the two continents. However, only sparse record of large grazing mammals, living in open areas, is found in the late Turolian. These taxa adapted to drier and more open environments. In Anatolia, the climate became more arid at the end of the late Miocene, resulting in relatively more open and sparse forest vegetation (Biltekin et al. 2015; Denk et al. 2018). Such aridity is also presented in the Baklan Basin with high $\delta^{18} \mathrm{O}$ isotopic values ( +0.25 to $+6.80 \%$ o $)$ of the lacustrine carbonates.

All of the fossil localities cropping out in the lowermost part of the infill of each basin have a similar age range of early-middle Turolian (MN11-12). Therefore, it appears that the SW Anatolian post-orogenic basins developed synchronously hosting the marginal alluvial fans along the basinbounding escarpments, fluvial deposits from streams running transversely and longitudinally along the basin axis and ephemeral lakes in the basin centre. Initially, the basins were underfilled as manifested by the size of potential accommodation space exceeding the rate of sediment supply, gradually filling with fining-upward sequences dominated by braided 
streams, punctuated by sheet-floods and laterally graded into meandering systems. Eventually, these fluvial systems were gradually drowned by shallow lacustrine marsh-swamp environments.

Phase II—Lacustrine period (early Pliocene to early Pleistocene)

The initial basin-fill composed of alluvial fan and fluvial deposits was subsequently drowned by extensive lakes by the early Pliocene. These initial lacustrine deposits are marked by facies assemblages of marsh-swamp environment, which abound in fossil micro-mammals, amphibians and molluscs. Such conditions are common for the balanced-fill lakes characterised by the sediment/water equilibrium with potential accommodation space (Carroll and Bohacs 1999). The timing of the lacustrine inundation has been well established based on biostratigraphy using microvertebrate remains from the locality of Ericek in the Çameli Basin (Alçiçek 2001; Alçiçek et al. 2005; Van den Hoek Ostende et al. 2015b). In the lowermost part of the lacustrine succession, cypriniform fish assemblages were reported by Rutte and Becker-Platen (1980) in the Baklan Basin; Alçiçek (2007) found similar cypriniform assemblages in the Essen Basin. New fossil mammals from the Sultandere locality of Burdur and the Afşar locality of Sandıklı yielded a Ruscinian age, supporting the lacustrine inundation throughout SW Anatolia implying warm and subhumid/humid climatic conditions at the time, for instance, the high proportion of desmanine moles. The early Pliocene subhumid/humid conditions are confirmed by very low $\delta^{18} \mathrm{O}$ isotopic values from the lacustrine carbonate deposits of the Denizli (Alçiçek et al. 2007) and Karacasu (Alçiçek and Jiménez-Moreno 2013) basins. Similar fossil mammal faunas reported by Saraç (2003) from the Bozarmut locality (MN14) in the Yatağan Basin indicates extend of lacustrine inundation further to the west. The Mio-Pliocene boundary is marked by a major faunal turnover in the Mediterranean mammal faunas, which in the east marks the end of the Pikermian fauna (Eronen et al. 2009). In SW Anatolia, this turnover is marked by the presence of various wood mice and a palaeobatrachid frog in the Ericek locality of the Çameli Basin (Van den Hoek Ostende et al. 2015b).

By the late Pliocene, the initially shallow lacustrine lakes gradually deepened as marked by thick, homogeneous marl and clayey limestone deposits. Palustrine carbonates were deposited in the margins of the deep lake environment, while deep lacustrine deposits were concentrated in the centres of the basins. The deep-water facies locally overlap the basin margins implying a lacustrine inundation following intermittent basin subsidence possibly owing to renewed extension. Eventually, the individual lakes were united to constitute a single mega-lake in prevailing for c $1 \mathrm{myr}$ in SW Anatolia during the Pliocene as speculated by Spratt and Forbes
(1847), Becker-Platen (1970), Luttig and Steffens (1976), Görür et al. (1995), and Görür (1998). Such a palaeo-lake environment was envisaged by Bering (1971) as the Pisidic Lake. Pamir (1974) has further extended this connection up the Denizli Basin to the north based on the presence of Cardium (Lymnocardiinae) assemblages (which likely refer to saline lake Cerastoderma, Didacna or Monodacna occurrences). The mollusc assemblages of the lacustrine phase are highly endemic and belong to a separate biogeographic unit, the Anatolian Bioprovince (Neubauer et al. 2015). In particular, the gastropod faunas show low affinities to other western Anatolian to northern Aegean assemblages but lesser relationships with surrounding peri-Paratethyan or southern Aegean faunas. Low $\delta^{18} \mathrm{O}(-7.98$ to $-6.38 \%)$ and $\delta^{13} \mathrm{C}(-7.71$ to $4.08 \%$ ) isotopic values of palustrine carbonates from the Çal Basin reflect a warm and subhumid climate in a landscape covered by $\mathrm{C} 3$-dominated forests or woodlands during the late Pliocene (Alçiçek and Alçiçek 2014).

Phase III—Basin dissection (early Pleistocene)

The adjoined lake basins that prevailed c. 1 myr during the Villanyian gradually and synchronously shrank by the early Pleistocene as indicated by a gradual transition of homogeneous lacustrine marls into shallow lacustrine marsh-swamp deposits. The shallow lacustrine environments abound in fossil micro- and macro-mammal assemblages across the entirety of SW Anatolia. Locations include the Bıçakçı locality in Çameli; Kırmızıtepe locality in Çal; Gelinören locality in Baklan; Yelalan locality in Acıgöl; and Kocakır, Elmacık, Yassıgüme and Ardıçtekke localities in Burdur basins (Alçiçek 2001; Alçiçek et al. 2005; Wesselingh and Alçiçek 2010; Alçiçek et al. 2012, 2013a; Demirel and Mayda 2014; Van den Hoek Ostende et al. 2015a; Alçiçek et al. 2017a, b). During this period, climatic changes led to more significant differentiation of Eurasian faunas from the east to west. Differences between Asian and western and eastern European faunas appeared. Early Pleistocene faunas from eastern Turkey are very similar to that of coeval faunas of the northern Black Sea region (Alçiçek et al. 2013b). These associations included meridionaloid elephants, monodactyl horses, bush-antlered deer and Leptobos bovids. The more open vegetation conditions are well reflected in the Bıçakçı fauna at the demise of the lacustrine period with warm and subhumid climatic conditions. These conditions are supported by low $\delta^{18} \mathrm{O}$ isotopic values: -8.89 to $-7.06 \%$ of the calcretes from the Çal Basin, -7.47 to $-2.13 \%$ of the molluscs from the Çameli Basin and -4.68 to $+0.21 \%$ of the fluvio-deltaic molluscs from the Denizli Basin. The low $\delta^{13} \mathrm{C}$ isotopic values $\left(-9.15\right.$ to $-6.17 \%$ ) and low organic $\delta^{13} \mathrm{C}$ isotopic values of the calcretes from the Çal Basin $(-27.88$ to $-24.57 \%$ ) are indicative of $\mathrm{C} 3$-dominated vegetation (forest or woodland), with a minor component of $\mathrm{C} 4$ plants 
(Alçiçek and Alçiçek 2014; Alçiçek et al. 2017a, b; Alçiçek et al. 2007). That fauna is dominated by hamsters (cricitines) and shows in addition a large variety of voles (microtines). Murids, which were dominant in the preceding period, now play a far more modest role (Van den Hoek Ostende et al. 2015a; Alçiçek et al. 2017a). The mollusc assemblages of that interval typically consist of widespread species still living today, which is in sharp contrast to the highly provincial character of the Pliocene lacustrine faunas (Neubauer et al. 2015).

During the early Pleistocene, a renewed pulse of extension prompted the deposition of coarse-grained alluvial fan sediments derived from the basin margins interfingering with the lacustrine sediments towards the basin centre. In this stage, the accommodation space was eventually exhausted, as is indicated by the basin-wide expansion of alluvial to fluvial sedimentation. This stage was attributed to a change in the direction of extension that is considered to have affected the entire area of SW Anatolia (Ten Veen 2004; Alçiçek et al. 2006; Ten Veen et al. 2009). During this phase, the united SW Anatolian lacustrine mega-basin became totally dissected. Lower Pleistocene coarse-grained alluvial fan deposits that unconformably overlie older Neogene units in SW Anatolia evidence the renewed extension. This alluvial unit has a distinct dark-red colour with prominent pedogenic horizons in the over-bank deposits. The succeeding (i.e. Holocene) period is characterised predominantly by degradation of topographic highs through deeply incising river erosion. Newly generated faults as well as reactivated faults are thought to have been associated with extension related to slab edge processes at the northern edge of the northwards subducting African slab below western Anatolia (Van Hinsbergen et al. 2010; Biryol et al. 2011; Kaymakçı et al. 2018), which further accentuated the basin-andrange topography of SW Anatolia (Alçiçek et al. 2005; Alçiçek 2007; Ten Veen et al. 2009).

\section{Conclusions}

The depositional architectures of SW Anatolian terrestrial basins are associated with multiple pulses of extension that resulted in palaeoenvironmental changes. Strongly correlative environmental changes in the basins are reflected by shifts of the faunal- and depositional assemblages. Stratigraphy and sedimentation patterns of the mammal-bearing strata in this Lycian orogen-top domain allow us to present a regional inter-basinal correlation and palaeobiogeographical reconstructions over the Anatolian gateway, which is uniquely located along the migration route critical to the fauna of the Old World. Biostratigraphic constraints in these basins have been reassessed with the support of new fossil findings to calibrate and constrain the spatio-temporal relationships of palaeoenvironments within a regional palaeogeographical framework. The fossil associations have been combined with the sedimentation pattern to refine the post-orogenic basin development and regional palaeobiogeography throughout the Lycian Taurides. This study reaffirms the synchronicity of the triparte nature of the sedimentation patterns in the various basins during late Miocene, Pliocene and early Pleistocene time intervals, each with its own particular environmental characteristics.

Terrestrial sedimentation on the Lycian hinterland had commenced by the late Tortonian (early Turolian) and postdate the latest marine transgression in the region that lasted until the late Burdigalian. This transgression followed a period of non-deposition covering the Langhian-Tortonian interval (c. 7 myr) and corresponds to a change from regional shortening to extension. In the early stage, the basins subsided to accommodate a transition from coarse-clastic alluvial fans and axial fluvial systems. According to $\delta^{18} \mathrm{O}$ isotopic data and mammal fauna, the warm and humid climate of the late Tortonian shifted to arid conditions during the late Messinian (late Turolian). The alluvial floodplain deposits from that period abound in large mammal taxa of the Pikermi fauna, implying an open, seasonal palaeoenvironment with forest steppe to grass-dominated steppe ecosystems. The terrestrial fossil assemblages from individual basins correlate with those of adjacent basins indicating palaeobiogeographical connections.

By the early Pliocene (late Ruscinian), a gradual transition from alluvial fan-dominated environments into axial fluvial-dominated systems, was accompanied with regional climatic variations. Conditions change into warm and subhumid/humid with forest steppe to steppe-type open habitats, based on $\delta^{18} \mathrm{O}$ isotopic data and mammal faunal content. This change subsequently gave way to base-level rise, lake expansion, descending relief and increased flow capacity. The humid condidions were sustained until the late Pliocene (early Villanyian), whence shallowpalustrine to lacustrine environments were widespread, comparable with modern lakes in SW Anatolia. The fossil associations underlying and overlying the Pliocene lacustrine deposits indicate a 1-myr duration for the united SW Anatolian mega-lake phase in SW Anatolia.

By the early Pleistocene (latest Villanyian), all Lycian orogen-top basins were dissected by newly generated faults and their configuration was re-arranged. The base-level changes resulted in coarse-clastic alluvial fan to fluvial material unconformably overlying the earlier deposits in the basins. This unit contains large mammal taxa representing an open and semi-open forest steppe to steppe-type ecosystem. The $\delta^{18} \mathrm{O}$ and $\delta^{13} \mathrm{C}$ isotopic data and mammal fauna indicate that climate was warm and humid during the late Pliocene to early Pleistocene.

Acknowledgements We thank N. Kaymakci (METU) and A. Brogi (Bari Univ.) for their constructive comments and W. Nemec (Bergen Univ.) for stimulating discussions that improved the paper considerably. 
Funding information We are grateful for the support of the international bilateral project between The Scientific and Technological Research Council of Turkey (TUBITAK) and The Russian Scientific Foundation (RFBR) with grant a number of 111Y192. M.C.A. is grateful to the Turkish Academy of Sciences (TUBA) for a GEBIP (Young Scientist Award) grant. T.K. and S.M. are grateful to the Ege University Scientific Research Center for the TTM/002/2016 and TTM/001/2016 projects. M.C.A., H.A., S.M. and M.B. have obtained Martin and Temmick Fellowships at Naturalis Biodiversity Center (Leiden). F.A.D. is supported by a Mehmet Akif Ersoy University Scientific Research Grant. T.A.N. is supported by an Alexander-von-Humboldt Scholarship. L.H.O. received support from TUBITAK under the 2221 program for visiting scientists.

\section{Compliance with ethical standards}

Conflict of interest The authors declare that they have no conflict of interest.

Open Access This article is distributed under the terms of the Creative Commons Attribution 4.0 International License (http:// creativecommons.org/licenses/by/4.0/), which permits unrestricted use, distribution, and reproduction in any medium, provided you give appropriate credit to the original author(s) and the source, provide a link to the Creative Commons license, and indicate if changes were made.

\section{References}

Akdeniz, N. (2011a). Geological maps of Turkey in 1:100.000 scale: Denizli N21 sheet. 41 pp. Ankara: Mineral Research and Exploration Directorate of Turkey (MTA).

Akdeniz, N. (2011b). Geological maps of Turkey in 1:100.000 scale: Denizli N22 sheet. 44 pp. Ankara: Mineral Research and Exploration Directorate of Turkey (MTA).

Alçiçek, M. C. (2001). Sedimentological investigation of the Çameli Basin (Late Miocene-Late Pliocene, Denizli, SW Anatolia). Unpubl. Ph.-D. Thesis, Ankara University, 101 pp.

Alçiçek, M. C. (2007). Tectonic development of an orogen-top rift recorded by its terrestrial sedimentation pattern: the Neogene Eșen Basin of southwestern Anatolia, Turkey. Sedimentary Geology, 200, 117-140.

Alçiçek, H. (2009). Late Miocene nonmarine sedimentation and formation of magnesites in the Acıgöl Basin, southwestern Anatolia, Turkey. Sedimentary Geology, 219, 115-135.

Alçiçek, H. (2010). Stratigraphic correlation of the Neogene basins in southwestern Anatolia: regional palaeogeographical, palaeoclimatic and tectonic implications. Palaeogeography, Palaeoclimatology, Palaeoecology, 291, 297-318.

Alçiçek, M. C. (2015). Comment on "The Fethiye-Burdur Fault Zone: a component of upper plate extension of the subduction transform edge propagator fault linking Hellenic and Cyprus Arcs, Eastern Mediterranean. Tectonophysics $635,80-99$ by J. Hall, A. E. Aksu, İ. Elitez, C. Yaltırak, G. Çiftçi”. Tectonophysics, 664, 1-4.

Alçiçek, H., \& Alçiçek, M. C. (2014). Palustrine carbonates and pedogenic calcretes in the Çal basin of SW Anatolia: implication on the Plio-Pleistocene regional climatic pattern in the eastern Mediterranean. Catena, 112, 48-55.

Alçiçek, H., \& Jiménez-Moreno, G. (2013). Late Miocene to Pliocene fluvio-lacustrine system in Karacasu Basin (SW Anatolia, Turkey): depositional, palaeogeographic and palaeoclimatic implications. Sedimentary Geology, 291, 62-83.
Alçiçek, M. C., \& Ten Veen, J. H. (2008). The late Early Miocene Acipayam piggy-back basin: refining the last stages of Lycian nappe emplacement in SW Turkey. Sedimentary Geology, 208, 101-113.

Alçiçek, M. C., Kazancı, N., \& Özkul, M. (2005). Multiple rifting pulses and sedimentation pattern in the Çameli Basin, southwestern Anatolia, Turkey. Sedimentary Geology, 173, 409-431.

Alçiçek, M. C., Ten Veen, J. H., \& Özkul, M. (2006). Neotectonic development of the Çameli Basin, southwestern Anatolia, Turkey. In A. H. F. Robertson \& D. Mountrakis (Eds.), Tectonic development of the eastern Mediterranean region (Vol. 260, pp. 591-611). London: Geological Society London Special Publication.

Alçiçek, H., Varol, B., \& Özkul, M. (2007). Sedimentary facies, depositional environments and palaeogeographic evolution of the Neogene Denizli Basin of SW Anatolia, Turkey. Sedimentary Geology, 202, 596-637.

Alçiçek, M. C., Mayda, S., \& Alçiçek, H. (2012). Faunal and palaeoenvironmental changes in the Çal Basin, SW Anatolia: implications for regional stratigraphic correlation of late Cenozoic basins. Comptes Rendus Geoscience, 344, 89-98.

Alçiçek, M. C., Brogi, A., Capezzuoli, E., Liotta, D., \& Meccheri, M. (2013a). Superimposed basin formation during NeogeneQuaternary extension in SW-Anatolia (Turkey): insights from the kinematics of the Dinar fault zone. Tectonophysics, 608, 713-727.

Alçiçek, M. C., Mayda, S., \& Titov, V. V. (2013b). Lower Pleistocene stratigraphy of the Burdur Basin of SW Anatolia. Comptes Rendus Palevol, 12, 1-11.

Alçiçek, H., Wesselingh, F. P., Alçiçek, M. C., Jiménez-Moreno, G., Feijen, F. J., Van den Hoek Ostende, L. W., Mayda, S., \& Tesakov, A. S. (2017a). A multiproxy study of the early Pleistocene palaeoenvironmental and palaeoclimatic conditions of an anastomosed fluvial sequence from the Cameli Basin (SW Anatolia, Turkey). Palaeogeography, Palaeoclimatology, Palaeoecology, 467, 232-252.

Alçiçek, M. C., Mayda, S., \& Demirel, A. (2017b). Discussion on "Neogene-Quaternary evolution of the Tefenni basin on the Fethiye-Burdur fault zone, SW Anatolia-Turkey. Journal of African Earth Science 118, 137-148 by R. Aksoy, S. Aksar1". Journal of African Earth Sciences, 134, 794-799.

Alçiçek, M. C., Van den Hoek Ostende, L. W., Saraç, G., Tesakov, A. S., Murray, A. M., Hakyemez, H. Y., Göktaş, F., Mayda, S., JiménezMoreno, G., Büyükmeriç, Y., Wesselingh, F. P., \& Alçiçek, H. (2018). Comment on "Miocene to Quaternary tectonostratigraphic evolution of the middle section of the Burdur-Fethiye Shear Zone, south-western Turkey: Implications for the wide inter-plate shear zones. Tectonophysics 690, 336-354". Tectonophysics, 722, 595600.

Alpagut, B., Mayda, S., Kaya, T., Göktas, F., Halaclar, K., \& Kesici, S. D. (2014). Overview of recent research on Muğla-Özlüce mammalian fossil locality. $67^{\text {th }}$ Geological Congress of Turkey.15-18 April 2014-Ankara, 732-733.

Alpagut, B., Kaya, T. T., Mayda, S., Demirel, A., \& Ekinci, H. A. (2015). Burdur-Elmacik Fossil Vertebrate Locality. $68^{\text {th }}$ Geological Congress of Turkey, 06-10 April 2015 Ankara. Abstracts, 498$499 \mathrm{pp}$.

Altınlı, İ. E. (1955). The geology of southern Denizli. Revue de la Faculté des Sciences de I'Université d'Istanbul. Serie B: Sciences Naturelles, 20(1-2), 1-47.

Angelier, J., Dumont, J. F., Karamanderesi, İ. H., Poisson, A., Șimșek, Ș., \& Uysal, Ș. (1981). Analyses of fault mechanism and expansion of southwestern Anatolia since Late Miocene. Tectonophysics, 75, T1T9.

Atalay, Z. (1980). Stratigraphy of continental Neogene in the region of Muğla-Yatağan, Turkey. Bulletin of the Geological Society of Turkey, 23, 93-99.

Athanassas, C. D., Modis, K., Alçiçek, M. C., \& Theodorakopoulou, K. (2018). Contouring the cataclysm: a geographical analysis of the 
effects of the Minoan eruption. Environmental Archaeology, 23(2), 160-176.

Becker-Platen, J. D. (1970). Lithostratigraphisce Untersuchungen im Känozoikum Südwest- Anatoliens (Türkei). Beihefte zum geologischen Jahrbuch, 97, 1-244.

Benda, L. (1971). Principles of the palynologic subdivision of the Turkish Neogene. Newsletters on Stratigraphy, 1-3, 23-26.

Bering, D. (1971). The development of the Neogene and Quaternary intramontane basins within the Pisidic lake district in S. Anatolia. Newsletters on Stratigraphy, 1, 27-32.

Bernor, R. L., Koufos, G. D., Woodburne, M. O., \& Fortelius, M. (1996). The evolutionary history and biochronology of European and Southwest Asian Late Miocene and Pliocene hipparionine horses. In R. L. Bernor, V. Fahlbusch, \& H. W. Mittmann (Eds.), The Evolution of Western Eurasian Neogene Mammal Faunas (pp. 307-338). New York: Columbia University Press.

Bernoulli, D., de Graciansky, P. C., \& Monod, O. (1974). The extension of the Lycian nappes (SW Turkey) into the southwestern Aegean islands. Eclogae Geologicae Helvetiae, 67, 39-90.

Biltekin, D., Popescu, S.-M., Suc, J.-P., Quézel, P., Jiménez-Moreno, G., Yavuz, N., \& Çağatay, M. N. (2015). Anatolia: a long-time plant refuge area documented by pollen records over the last 23 million years. Review of Palaeobotany and Palynology, 215, 1-22.

Biryol, C. B., Beck, S. L., Zandt, G., \& Özacar, A. A. (2011). Segmented African lithosphere beneath the Anatolian region inferred from teleseismic P-wave tomography. Geophysical Journal International, 184(3), 1037-1057.

Bouchal, J. M. (in press). The middle Miocene palynofloras of the Salihpaşalar lignite mine (Yatağan Basin, southwest Anatolia): environmental characterisation and comparison with coeval palynofloras from adjacent subbasins. In L.W. van den Hoek Ostende (Ed.) Taking the Orient Express? The role of Anatolia in mediterranean Neogene palaeobiogeography Palaeobiodiversity and Palaeoenvironments, 1-46. https://doi.org/10.1007/s12549018-0345-0. [this issue].

Bozkurt, E. (2003). Origin of NE-trending basins in western Turkey. Geodinamica Acta, 16, 61-81.

Büyükmeriç, Y. (2017). Molluscan biostratigraphy of early Miocene deposits of Kale-Tavas and Acıpayam basins (Denizli, SW Turkey). Bulletin of the Mineral Research and Exploration, 155, 15-30.

Büyükmeriç, Y., \& Wesselingh, F. P. (2018). New cockles (Bivalvia: Cardiidae: Lymnocardiinae) from Late Pleistocene Lake Karapınar (Turkey): discovery of a Pontocaspian refuge? Quaternary International, 465(A), 37-45.

Carroll, A. R., \& Bohacs, K. M. (1999). Stratigraphic classification of ancient lakes: balancing tectonic and climatic controls. Geology, 27, 99-102.

Cihan, M., Saraç, G., \& Gökçe, O. (2003). Insights into biaxial extensional tectonics: an example form the Sandiklı Graben, West Anatolia, Turkey. Geological Journal, 38, 47-46.

Cipollari, P., Cosentino, D., \& Gliozzi, E. (1999). Extension- and compression-related basins in central Italy during the Messinian Lago-Mare event. Tectonophysics, 315, 163-185.

Çoban, H., Topuz, G., Roden, M. F., Hoang, N., \& Schwarz, W. H. (2019). Ar- Ar dating and petrology of monzonite ejecta in tephra from Quaternary Gölcük volcano (Isparta, SW Turkey): tear-related contrasting metasomatic symptoms in extensional mantle-derived magmas. Lithos, 330-331, 160-176.

Colin, H. J. (1962). Geologische Untersuchungen im Raume Fethiye, Anatalya, Kaș, Finike (SW Anatolien). Bulletin of the Mineral Research and Exploration, 59, 19-61.

Collins, A. S., \& Robertson, A. H. F. (1997). Lycian mélange, southwestern Turkey: an emplaced Late Cretaceous accretionary complex. Geology, 25, 255-258.

Collins, A. S., \& Robertson, A. H. F. (1998). Processes of Late Cretaceous to Late Miocene episodic thrust-sheet translations in the Lycian Taurides, SW Turkey. Journal of the Geological Society of London, 155, 759-772.

Collins, A. S., \& Robertson, A. H. F. (1999). Evolution of the Lycian Allochthon, western Turkey, as a north-facing Late Palaeozoic to Mesozoic rift and passive continental margin. Geological Journal, 34, 107-138.

Collins, A. S., \& Robertson, A. H. F. (2003). Kinematic evidence for Late Mesozoic-Miocene emplacement of the Lycian Allochthon over the Western Anatolide Belt, SW Turkey. Geological Journal, 38, 295-310.

Darbaș, G. (2017). Stratigraphy and ostracod assemblages of the Çameli Formation crop out Dalaman-Göcek (Muğla-SW Turkey), $17^{\text {th }}$ International Multidisciplinary Scientific Geoconference, 11, pp. $531-539$.

De Graciansky, P.-C. (1972). Reserches géologiques dans le Taurus Lycien occidental. Thèse Doctorat d'Etat, Université de Paris-Sud Orsay no. 896, 762 pp.

Demirel, A., \& Mayda, S. (2014). A new early Pleistocene mammalian fauna from Burdur Basin, SW Turkey. Russian Journal of Theriology, 13, 55-63.

Demirel, A., Mayda, S., Alçiçek, M. C., Kaya, T. T., \& Aytek, A. İ. (2016). Kocakir-2: first record of Early Pleistocene Canis and Hippopotamus from Burdur Basin (SW Turkey). XIV EAVP Meeting, 6-10 July, 2016, Haarlem, The Netherlands. p. 39.

Demirel, A., Mayda, S., Alçiçek, M. C., Kaya, T. T., \& Aytek, A. İ. (2017). Burdur ili ve ilçelerinde Neojen ve Pleistosen dönem fosil lokalitelerinin tespiti yüzey araștırması-2015. TCKB 34. Araştırma Sonuçları Toplantısl, 2, 245-255.

Demory, F., Lebatard, A-E., Perrin, M., Rochette, P., Bourles, D., Alçiçek, H., Nomade, S., Rambeau, C., Andrieu-Ponel, V., Helvac1, C., \& Alçiçek, M. C. (2018). A 2.4 Ma. lacustrine record from Lake Acigöl (Turkey) with a high paleoclimatic archive potential. Colloque Q11 sur le Quaternaire, 13-15 Fevrier, Orleans, France.

Denk, T., Zohner, C. M., Grimm, G. W., \& Renner, S. S. (2018) Plant fossils reveal major biomes occupied by the late Miocene Old-World Pikermian fauna. Nature Ecology \& Evolution, 2(12), 1864-1870.

Dumont, J. F., Uysal, Ș., Șimşek, Ș., Karamanderesi, İ. H., \& Letouzey, J. (1979). Formation of the grabens in southwestern Anatolia. Bulletin of the Mineral Research and Exploration, 92, 7-18.

Elitez, İ., Yaltırak, C., \& Sunal, G. (2017). A new chronostratigraphy (40Ar-39Ar and $\mathrm{U}-\mathrm{Pb}$ dating) for the middle section of the Burdur-Fethiye shear zone, SW Turkey. Geophysical Research Abstract, 19, EGU2017-EGU5443.

Erakman, B., \& Alkan, H. (1986). Kalkan-Elmalı-Yeșilova-AcipayamFethiye Arasının Jeoloji ve Petrol Olanakları (Geological and Oil Possibilities of the Area Between Kalkan-Elmal1-YeșilovaAcıpayam-Fethiye). TPAO Raporu No: 2190 (unpublished).

Erakman, B., Meșhur, M., Gül, M. A., Alkan, H., Öztaș, Y., \& Akpınar, M. (1982a). Fethiye-Köyceğiz-Tefenni-Elmalı-Kalkan arasında kalan alanın jeolojisi. Türkiye 6. Petrol Kongresi, Ankara s. pp. 23-31.

Erakman, B., Meşhur, M., Gül, M.A., Alkan, H., Öztaş, Y., \& Akpınar, M. (1982b). Toros projesine bağlı Kalkan-Köyceğiz-CameliTefenni arasında kalan alanın jeolojisi ve hidrokarbon olanakları raporu (The geology and hydrocarbon potential of the KalkanKöyceğiz-Çameli-Tefenni region, as a part of The Taurus Project). Ankara: The Turkish Petroleum Corporation (TPAO), Technical Report No: 1732.

Eronen, J. T., Ataabadi, M. M., Micheels, A., Karme, A., Bernor, R. L., \& Fortelius, M. (2009). Distribution history and climatic controls of the late Miocene Pikermian chronofauna. Proceedings of the National Academy of Science of the United States of America, 106, pp. 11867-11871.

Fischer, P. (1866-1869). Faune tertiaire lacustre. In P. de Tchihatcheff, A. d'Archiac, P. Fischer, \& E. de Verneuil (Eds.), Asie mineure: description physique de cette contrée. Paléontologie (pp. 327-354). Paris: Librairie Théodore Morgand. 
Geraads, D. (2017). Late Miocene large mammals from Mahmutgazi, Denizli province, Western Turkey. Neues Jahrbuch für Geologie und Paläontologie, Abhandlungen, 284(3), 241-257.

Göktaş, F., Çakmakoğlu, A., Tarı, E., Sütçü, Y. F., \& Sarıkaya, H. (1989). Civril-Çardak arasının jeolojisi. Mineral Research and Exploration Directorate of Turkey (MTA), Report No: 8701, pp. 1-109.

Görür, N. (Ed.) (1998). Triassic to Miocene Palaeogeographic Atlas of Turkey. 43 pp. Istanbul: Publication of İstanbul Technical University and Mineral Research and Explonation Directorate of Turkey (MTA).

Görür, N., Sakınç, M., Barka, A., Akkök, R., \& Ersoy, Ș. (1995). Miocene to Pliocene paleogeographic evolution of Turkey and its surroundings. Journal of Human Evolution, 28, 309-324.

Guillou, H., Vincent, S., Nomade, S., Platevoet, B., \& Blamart, D. (2017). Des la justesse des ages K-Ar: Exemple de la datation de deux domes trachytiques du Gölcük (Turquie). Quaternaire, 28, 141148

Hakyemez, H. Y. (1989). Geology and stratigraphy of the Cenozoic sedimentary rocks in the Kale-Kurbalık area, Denizli, southwestern Turkey. Bulletin of Mineral Research and Exploration, 109, 1-14.

Hakyemez, H. Y., \& Örçen, S. (1982). Muğla ve Denizli arasındaki (Güneybatı Anadolu) Senozoyik yaşlı çökel kayaların sedimantolojik ve biyostratigrafik incelemesi. Mineral Research and Exploration Directorate of Turkey (MTA), Report No: 7311, pp. $1-237$.

Hayward, A. B. (1984). Sedimentation and basin formation related to ophiolite emplacement, Miocene, SW Turkey. Sedimentary Geology, 40, 105-129.

Hayward, A. B., \& Robertson, A. H. F. (1982). Direction of ophiolite emplacement inferred from Cretaceous and Tertiary sediments of an adjacent autochthon, the Bey Dağlari, SW Turkey. Geological Society of America Bulletin, 93, 68-75.

Helvacı, C., Alçiçek, M. C., Gündoğan, İ., \& Gemici, Ü. (2013). Tectonosedimentary development and palaeoenvironmental changes in the Acıgöl shallow-perennial playa-lake basin, SW Anatolia, Turkey. Turkish Journal of Earth Sciences, 22, 173-190.

Hilgen, F. J., Lourens, L. J., \& Van Dam, J. A. (2012). The Neogene period. In F. M. Gradstein, J. G. Ogg, M. Schmitz, \& G. Ogg (Eds.), The Geologic Time Scale 2012 (pp. 923-978). Oxford: Elsevier.

Howell, A., Jakckon, J., Copley, A., McKenzie, D., \& Nissen, E. (2017). Subduction and vertical coastal motions in the eastern Mediterranean. Geophysical Journal International, 211, 593-620.

İslamoğlu, Y., Atay, G., Gedik, F., Aydın, A., Hakyemez, A., Babayiğit, S., \& Sarıkaya, H. (2005). Batı Toroslar'daki Denizel OligoMiyosen çökellerinin biyostratigrafisi. Mineral Research and Exploration Directorate of Turkey (MTA), Report No: 10763, pp. $1-155$.

Jiménez-Moreno, G., Popescu, S.-M., Ivanov, D., \& Suc, J.-P. (2007). Neogene flora, vegetation and climate dynamics in southeastern Europe and northeastern Mediterranean according to pollen records. In M. Williams, A.-M. Haywood, F. J. Gregory, \& D. N. Schmidt (Eds.), Deep-time perspectives on climate change: marrying the signal from computer models and biological proxies (pp. 503516). London: The Micropalaeontological Society, Special Publications. The Geological Society.

Jiménez-Moreno, G., Alçiçek, H., Alçiçek, M. C., Van den Hoek Ostende, L. W., \& Wesselingh, F. P. (2015). Vegetation and climatic cycles during the late Pliocene and early Pleistocene in SW Anatolia. Turkey. Quaternary Research, 84, 448-456.

Jiménez-Moreno, G., Alçiçek, H., Alçiçek, M. C., Van den Hoek Ostende, L. W., \& Wesselingh, F. P. (2016). Letter to Editor "Vegetation and climatic cycles during the late Pliocene and early Pleistocene in SW Anatolia" response to comments. Quaternary Research, 85, 476- 477.

Jolivet, L., Menant, A., Sternai, P., Rabillard, A., Arbaret, L., Augier, R., Laurent, V., Beaudoin, A., Grasemann, B., Huet, B., Labrousse, L.,
\& Le Pourhiet, L. (2015). The geological signature of a slab tear below the Aegean. Tectonophysics, 659, 166-182.

Kahlke, R.-D., García, N., Kostopoulos, D. S., Lacombat, F., Lister, A. L., Mazza, P., Spassov, N., \& Titov, V. V. (2011). Western Palaearctic palaeoenvironmental conditions during the Early and early Middle Pleistocene inferred from large mammal communities, and implications for hominin dispersal in Europe. Quaternary Science Reviews, 30, 1368-1395.

Karabacak, V. (2011). Geological, geomorphological and archeoseismological observations along the Cibyra fault and their implications on the regional tectonic of SW Turkey. Turkish Journal of Earth Sciences, 20, 429-447.

Karaman, E. (1986). Burdur dolayının genel stratigrafisi. Akdeniz. Üniversitesi Isparta Mühendislik Fakültesi Dergisi, 2, 23-36.

Kaya, T. (1993). Late Miocene Perissodactyla from Sazak (Kale-Denizli). Bulletin of the Mineral Research and Exploration, 115, 23-31.

Kaya, T., \& Forstén, A. (1999). Late Miocene Ceratotherium and Hipparion (Mammalia, Perissodactyla) from Düzyayla (Hafik, Sivas), Turkey. Geobios, 32, 743-748.

Kaya, T., Mayda, S., \& Alçiçek, M. C. (2008). Denizli - Çal Yöresinde Yeni bir Geç Miyosen Memeli faunası. Proc. IX Palaentol.Stratigraphy Confer. Denizli, Turkey.

Kaya, T., Mayda, S., Kostopoulos, D., Alçiçek, M. C., Merceron, G., Tan, A., Karakütük, S., Giesler, A. K., \& Scott, S. S. (2012). Șerefköy-2, a new late Miocene mammalian locality from the Yatağan formation, Muğla, SW Turkey. Comptes Rendus Palevol, 11, 5-12.

Kaymakçı, N. (2006). Kinematic development and paleostress analysis of the Denizli Basin (Western Turkish): implications of spatial variation of relative paleostress magnitudes and orientations. Journal of Asian Earth Sciences, 27, 207-222.

Kaymakçı, N., Langereis, C., Özkaptan, M., Özacar, A. A., Gülyüz, E., Uzel, B., Sözbilir, H., \& Koç, A. (2018). Paleomagnetic evidences for upper plate response to a STEP fault, SW Anatolia. Earth and Planetary Science Letters, 498, 101-115.

Koç, A., Van Hinsbergen, D. J. J., Kaymakç1, N., \& Langereis, C. G. (2016). Late Neogene oroclinal bending in the central Taurides: a record of terminal eastward subduction in southern Turkey? Earth and Planetary Science Letters, 434, 75-90.

Koçyiğit, A., \& Deveci, S.. (2007). A N-S-trending active extensional structure, the Şuhut (Afyon) graben: commencement age of the extensional neotectonic period in the Isparta Angle, SW Turkey. Turkish Journal of Earth Sciences, 16, 391-416.

Konak, N. (2002). Geological map of Turkey in 1/500.000 scale: İzmir sheet. Ankara: Mineral Research and Exploration Directorate of Turkey (MTA).

Konak, N., \& Șenel, M. (2002). Geological map of Turkey in 1/500.000 scale: Denizli sheet. Ankara: Mineral Research and Exploration Directorate of Turkey (MTA).

Konak, N., Akdeniz, N., \& Çakir, M. H. (1986). Çal-Çivril-Karahallı dolayının jeolojisi. Mineral Research and Exploration Institution of Turkey (MTA), Report No: 8945, pp. 1-122.

Kostopoulos, D. S., \& Karakütük, S. (2015). Late Miocene bovids from Șerefköy-2, SW Turkey, and their position within the subParatethyan biogeographic province. Acta Palaeontologica Polonica, 60(1), 49-66.

Koufos, G. D., \& Kostopoulos, D. S. (1994). The late Miocene mammal localities of Kemiklitepe (Turkey). 3. Equidae. Bulletin du Muséum national d'Histoire naturelle Paris 4 e sér., 16, pp. 41-80.

Koufos, G. D., Mayda, S., \& Kaya, T. (2018). New carnivoran remains from the late Miocene of Turkey. Paläontologische Zeitschrift, 92(1), 131-162.

Krijgsman, W., Tesakov, A. S., Yanina, T., Lazarev, S., Danukalova, G., Van Baak, G. C. G., Agustí, J., Alçiçek, M. C., Aliyeva, E., Bista, D., Bruch, A., Büyükmeriç, Y., Bukhsianidze, M., Flecker, R., Frolov, P., Hoyle, T. M., Jorissen, E. L., Kirscher, U., Koriche, S. A., Oms, O., Rausch, L., Singarayer, J., Stoica, M., Van de Velde, S. 
V., Titov, V. V., \& Wesselingh, F. P. (2019). Quaternary time scales for the Pontocaspian domain: interbasinal connectivity and faunal evolution. Earth-Science Reviews, 188, 1-40.

Lefevre, C., Bellon, H., \& Poisson, A. (1983). Presence de leucitites dans le volcanisme Pliocene de la region d'Isparta (Taurus occidentales, Turkquie). Comptes Rendus de l'Académie des Sciences de Paris, 297, 369-372.

Luttig, G., \& Steffens, D. (1976). Explanatory notes for the paleogeographic atlas of Turkey from Oligocene to Pleistocene. $64 \mathrm{pp}$. Hannover: Bundesanstalt für Geowissenschaften und Rohstoffe.

Mayda, S., Alçiçek, M. C., Demirel, F. A., \& Alçiçek, H. (2017). The first record of a Villafranchian small cervid "Croizetoceros" from Turkey. $15^{\text {th }}$ RCMNS Congress (Regional Committee on Mediterranean Neogene Stratigraphy), 3-6 September, Athens, Greece.

Meșhur, M., \& Akpınar, M. (1984). Yatağan-Milas-BodrumKaracasu-Kale-Acıpayam-Tavas civarlarının jeolojisi ve petrol olanakları (The geology and petroleum potential of YatağanMilas-Bodrum-Karacasu-Kale-Acıpayam-Tavas region). Ankara: The Turkish Petroleum Corporation (TPAO), Technical Report No: 1963.

Nemec, W., Kazanc1, N., \& Mitchell, J. G. (1998). Pleistocene explosions and pyroclastic currents in west-central Anatolia. Boreas, 27, 311332.

Nemec, W., Alçiçek, M. C., \& Özaksoy, V. (2018). Sedimentation in a foreland basin within synorogenic orocline: Palaeogene of the Isparta Bend, Taurides, SW Turkey. Basin Research, 30, 650-670.

Neubauer, T. A., Harzhauser, M., Kroh, A., Georgopoulou, E., \& Mandic, O. (2015). A gastropod-based biogeographic scheme for the European Neogene freshwater systems. Earth-Science Reviews, 143, 98-116.

Okay, A. I., Tansel, I., \& Tüysüz, O. (2001). Obduction, subduction and collision as reflected in the Upper Cretaceous-lower Tertiary sedimentary record of western Turkey. Geological Magazine, 138, 117142

Oppenheim, P. (1919). Das Neogen in Kleinasien. Zeitschrift Deutsche Geologische Gesellschaft, 70, 1-210.

Oruç, S. (2009). The fossils of Bovidae (Artiodactyla) from Denizli (Sazak) neogene mammalian fauna and their biochronological, paleobiogeographic and paleoclimatologic meanings. MSc Thesis. Ege University (Unpublished). İzmir. 154 pp.

Över, S., Pınar, A., Özden, S., Yılmaz, H., Ünlügenç, U. C., \& Kamacı, Z. (2010). Late Cenozoic stress field in the Cameli Basin, SW Turkey. Tectonophysics, 492, 60-72.

Över, S., Özden, S., Yılmaz, H., Pınar, A., Ünlügenç, U. C., \& Kamac1, Z. (2013a). Plio-Quaternary stres regime in the Eșen Çay Basin, SW Turkey. In A. H. F. Robertson, O. Parlak, \& U. C. Ünlügenç (Eds.), Geological Development of Anatolia and the Easternmost Mediterranean Region (Vol. 372, pp. 547-560). London, Special Publications: Geological Society.

Över, S., Yılmaz, H., Pınar, A., Özden, S., Ünlügenç, U. C., \& Kamacı, Z. (2013b). Plio-Quaternary stress state in the Burdur Basin, SW Turkey. Tectonophysics, 588, 56-68.

Över, S., Özden, S., Kamacı, Z., Yılmaz, H., Ünlügenç, U. C., \& Pınar, A. (2016a). Upper crust response to geodynamic processes beneath Isparta Angle, SW Turkey: revealed by CMT solution of earthquakes. Tectonophysics, 687, 94-104.

Över, S., Özden, S., Pınar, A., Yılmaz, H., Kamacı, Z., \& Ünlügenç, U. C. (2016b). Late Cenozoic stres state distributions at the intersection of the Hellenic and Cyprus arcs, SW Turkey. Journal of Asian Earth Sciences, 132, 94-102.

Özalp, S., Emre, Ö., Şaroğlu, F., Özaksoy, V., Elmacı, H., \& Duman, T. Y. (2018). Active fault segmentation of the Çivril Graben System and surface rupture of the 1 October 1995 Dinar earthquake (Mw 6.2), Southwestern Anatolia, Turkey. Journal of Asian Earth Sciences, 166, 136-151.

Özcan, E., Less, G., Báldi-Beke, M., Kollányi, K., \& Acar, F. (2009). OligoMiocene foraminiferal record (Miogypsinidae, Lepidocyclinidae and Nummulitidae) from the Western Taurides (SW Turkey): biometry and implications for the regional geology. Journal of Asian Earth Sciences, $34,740-760$.

Özgül, N. (1976). Toroslar'ın bazı temel jeoloji özellikleri. Bulletin of the Geological Society of Turkey, 19, 65-78.

Özgül, N. (1984). Stratigraphy and tectonic evolution of the Central Taurides. In. O. Tekeli, \& M. C. Göncüoğlu (Eds.), Geology of the Taurus belt. Proceedings of the International Symposium 26-29 September 1983 (pp. 77-90). Ankara: Mineral Research and Exploration Directorate of Turkey (MTA).

Özgül, N., \& Arpat, E. (1973). Structural units of the Taurus oceanic belt and their continuation in the neighbouring regions. Bulletin of the Geolical Society of Greece, 10, 156-164.

Özkaptan, M., Kaymakçı, N., Langereis, C. G., Gülyüz, E., Özacar, A., Uzel, B., \& Sözbilir, H. (2018). Age and kinematics of the Burdur Basin: inferences for the existence of the Fethiye Burdur fault zone in SW Anatolia (Turkey). Tectonophysics, 744, 256-274.

Özsayın, E. (2016). Relative tectonic activity assessment of the Çameli Basin, Western Anatolia, using geomorphic indices. Geodinamica Acta, 28, 241-253.

Pamir, H. N. (1974). 1/500 000 ölçekli Türkiye jeoloji haritası (Denizli). $83 \mathrm{pp}$. Ankara: Maden Tetkik ve Arama Enstitüsü yayını.

Paton, S. M. (1992). The relationship between extension and volcanism in western Turkey, the Aegean Sea, and central Greece. Unpubl. Ph.D. Thesis, Cambridge University, 300 pp.

Pickford, M. (2016). Hippopotamodon erymanthius (Suidae, Mammalia), from Mahmutgazi, Denizli-Çal Basin, Turkey. Fossil Imprint, 72, 183-201.

Platevoet, B., Scaillet, S., Guillou, H., Blamart, D., Nomade, S., Massault, M., Poisson, A., Elitok, Ö., Özgŭr, N., Yağmurlu, F., \& Y1lmaz, K. (2008). Pleistocene eruptive chronology of the Gölcük volcano, Isparta Angle, Turkey. Quaternaire, 19, 147-156.

Poisson, A. (1984). The extension of the Ionian trough into southwestern Turkey. In J. E. Dixon \& A. H. F. Robertson (Eds.), The Geological Evolution of the Eastern Mediterranean (Vol. 17, pp. 241-249). London, Special Publication: Geological Society of London.

Poisson, A., Yağmurlu, F., Bozcu, M., \& Șentürk, M. (2003). New insights on the tectonic setting and evolution around the apex of the Isparta Angle (SW Turkey). Geological Journal, 38, 257-282.

Price, S. P. (1989). Sedimentation and neotectonics of the Burdur region, SW Turkey. Unpubl. PhD Thesis, University of Leicester.

Price, S. P., \& Scott, B. C. (1989). A revised lithostratigraphy of the Burdur Formation, SW Turkey. Bulletin of the Technical University Istanbul, 42, 1-27.

Price, S. P., \& Scott, B. (1991). Pliocene Burdur basin, SW Turkey: tectonics, seismicity and sedimentation. Journal of the Geological Society of London, 148, 345-354.

Price, S. P., \& Scott, B. (1994). Fault-block rotations at the edge of a zone of continental extension: southwest Turkey. Journal of Structural Geology, 16(3), 381-392.

Robertson, A. H. F., \& Dixon, J. E. (1984). Introduction: aspects of the geological evolution of the eastern Mediterranean. In J. E. Dixon \& A. H. F. Robertson (Eds.), The Geological Evolution of the Eastern Mediterranean (Vol. 17, pp. 1-74). London, Special Publication: Geological Society of London. 
Robertson, A. H. F., Poisson, A., \& Akıncı, Ö. (2003). Developments in research concerning Mesozoic-Tertiary Tethys and neotectonics in the Isparta Angle, SW Turkey. Geological Journal, 38, 195-234.

Rutte, E., \& Becker-Platen, J. D. (1980). Cypriniden-Schlundzähne (Pisces) aus dem Känozoikum der Türkei. Newsletters on Stratigraphy, 8, 191-222.

Saraç, G. (2003). Türkiye omurgalı fosil yatakları. Mineral Research and Exploration Directorate of Turkey (MTA), Report No. 10609, 1208.

Schmidt-Kittler, N. (1976). Carnivores from the Neogene of Asia Minor. Palaeontographica, Abteilung A.: Paläozoologie-Stratigraphie, 155, pp. 1-131.

Schmitt, A. K. Danišík, M., Siebel, W., Elitok, Ö., Chang, Y-W. \& Shen, C-C. (2014). Late Pleistocene zircon ages for intracaldera domes at Gölcük (Isparta, Turkey). Journal of Volcanology and Geothermal Research, 286, 24-29.

Șen, Ș. (1977). La faune de Rongeurs pliocène de Çalta (Ankara, Turquie). Bulletin du Muséum national d'histoire naturelle, 3(61), $89-171$.

Șen, Ș. (1998). Rodentia and Lagomorpha. In. Ș. Șen (Ed.), Pliocene vertebrate locality of Çalta, Ankara, Turkey. Geodiversitas, 20(3), 359-378.

Şen, Ş, De Bonis, L., Dalfes, N., Geraads, D., Koufos, G. (1994). Les gisements de mammifères du Miocène supérieur de Kemiklitepe, Turquie: 1. Stratigraphie et magnétostratigraphie. Bulletin $d u$ Muséum national d'Histoire naturelle, Paris, 4e sér., section $C$, 16(1), 5-17.

Șenel, M. (1997a). Geological maps of Turkey in 1:100 000 scale: Isparta K10 sheet. 20 pp. Ankara: Mineral Research and Exploration Directorate of Turkey (MTA).

Şenel, M. (1997b). Geological maps of Turkey in 1:100.000 scale: Isparta J10 sheet. 18 pp. Ankara: Mineral Research and Exploration Directorate of Turkey (MTA).

Șenel, M. (1997c). Geological maps of Turkey in 1:100.000 scale: Denizli J9 sheet. $18 \mathrm{pp}$. Ankara: Mineral Research and Exploration Directorate of Turkey (MTA).

Şenel, M. (2002). Geological map of Turkey in 1/500.000 scale: Konya sheet. Ankara: Mineral Research and Exploration Directorate of Turkey (MTA).

Șenel, M. (2010). Geological maps of Turkey in 1:100.000 scale: Denizli N23 sheet. 20 pp. Ankara. Mineral Research and Exploration Directorate of Turkey (MTA)

Şenel, M., Selçuk, H., Bilgin, Z. R., Șen, A. M., Karaman, T., Dinçer, M. A., Durukan, E., Arbas, A., Örçen, S., \& Bilgi, C. (1989). Çameli (Denizli)-Yeşilova (Burdur)-Elmalı (Antalya) ve dolayının jeolojisi. Mineral Research and Exploration Directorate of Turkey (MTA), Report No: 9429, pp. 1-344.

Sengör, A. M. C., \& Y1lmaz, Y. (1981). Tethyan evolution of Turkey: a plate tectonic approach. Tectonophysics, 75, 181-241.

Șengör, A. M. C., Görür, N., \& Șaroğlu, F. (1985). Strike-slip deformation, basin formation and sedimentation: strike-slip faulting and related basin formation in zones of tectonic escape: Turkey as a case study. In K. B. Biddle \& N. C. Blick (Eds.), Strike-slip deformation, basin formation and sedimentation (Vol. 37, pp. 227-264). Tulsa: SEPM Special Publications.

Seyitoğlu, G., Alçiçek, M. C., Ișık, V., Alçiçek, H., Mayda, S., Varol, B., Y1lmaz, İ., \& Esat, K. (2009). The stratigraphical position of Kemiklitepe fossil locality (Uşak-Eşme) revisited: Implications for the Late Cenozoic sedimentary basin development and extensional tectonics in western Turkey. Neues Jahrbuch für Geologie und Paläontologie, 251(1), 1-15.
Sickenberg, O., \& Tobien, H. (1971). New Neogene and Lower Quaternary vertebrate faunas in Turkey. Newsletters on Stratigraphy, 1, 51-61.

Sickenberg, O., Becker-Platen, J. D., Benda, L., Berg, D., Engesser, B., Gazlry, W., Heissig, K., Hünermann, K. A., Sondaar, P. Y., SchmidtKittler, N., Staesche, K., Staesche, U., Steffens, P., \& Tobien, H. (1975). Die Gliederung des höheren Jungtertiärs und Altquartärs in der Türkei nach Vertebraten und ihre Bedeutung für die internationale Neogen-Stratigraphie. Geologisches Jahrbuch, Reihe B, 15, 1-167.

Sözbilir, H. (2005). Oligo-Miocene extension in the Lycian orogen: evidence from the Lycian mollase basin, SW Turkey. Geodinamica Acta, 18, 255-282.

Spratt, T. A. B., \& Forbes, E. (1847). Travels in Lycia, Milyas and the Cibyrates. 244 pp. London: Van Voorst.

Sulpizio, R., Alçiçek, M. C., Zanchetta, G., \& Solari, L. (2013). Recognition of the Minoan tephra in the Acigol Basin, western Turkey: implications for inter archive correlations and fine ash dispersal. Journal of Quaternary Science, 28, 329-335.

Sun, S. (1990). Denizli-Ușak arasının jeolojisi ve linyit olanakları. Mineral Research and Exploration Directorate of Turkey (MTA), Report No: 9985, pp. 1-92.

Sylvestrou, I. A., \& Kostopoulos, D. S. (2007). Pseudomeriones megistos nov. sp. (Gerbillinae, Mammalia) from the latest Miocene of Northern Greece and its phylogenetic relationships. Geobios, 40, 833-848.

Ten Veen, J. H. (2004). Extension of Hellenic forearc shear zones in SW Turkey: the Pliocene-Quaternary deformation of the Eșen Çay Basin. Journal of Geodynamics, 37, 181-204.

Ten Veen, J. H., Boulton, S. J., \& Alçiçek, M. C. (2009). From palaeotectonics to neotectonics in the Neotethys realm: the importance of kinematic decoupling and inherited structural grain in SW Anatolia (Turkey). Tectonophysics, 473, 261-281.

Tuna, V. (1999). Yukarısazak (Kale-Denizli) Geç Miyosen Artiodactyl'leri (Mammalia). MTA Dergisi, 121, 73-82.

Tunoğlu, C., \& Bayhan, E. (1996). Burdur Havzası Pliyosen istifinin mikropaleontolojik (ostracod) incelemesi ve ortamsal yorum. MTA Dergisi, 118, 9-16.

Turan, N. (2002). Geological map of Turkey in 1/500.000 scale: Ankara sheet. Ankara: Mineral Research and Explaniton Directorate of Turkey (MTA).

Van den Hoek Ostende, L. W., Diepeveen, F., Tesakov, A. S., Saraç, G., Mayhew, D., \& Alçiçek, M. C. (2015a). On the brink: micromammals from the latest Villanyian from Bıçakçı (Anatolia). Geological Journal, 50, 230-245.

Van den Hoek Ostende, L. W., Gardner, J. D., Van Bennekom, L., Alçiçek, M. C., Murray, A. M., Wesselingh, F. P., Alçiçek, H., \& Tesakov, A. S. (2015b). Ericek, a new Pliocene vertebrate locality from the Cameli Basin (SW Anatolia, Turkey). Palaeobiodiversity and Palaeoenvironments, 95, 305-320.

Van Hinsbergen, D. J. J., Kaymakçı, N., Spakman, W., \& Torsvik, T. H. (2010). Reconciling the geological history of western Turkey with plate circuits and mantle tomography. Earth and Planetary Science Letters, 297, 674-686.

Vialet, A., Guipert, G., \& Alçiçek, M. C. (2012). Homo erectus found still further west: reconstruction of the Kocabaș cranium (Denizli, Turkey). Comptes Rendus Palevol, 11, 89-95.

Waldron, J. W. F. (1981). Mesozoic sedimentary and tectonic evolution of the northeast Antalya Complex, Eğridir, SW. Turkey. Ph.D. Thesis, Edinburg University, $312 \mathrm{pp}$.

Wenz, W. (1919). Zur Nomenklatur tertiärer Land- und Süßwassergastropoden. I. Nachrichtsblatt der Deutschen Malakozoologischen Gesellschaft, 51(2), 68-76. 
Wesselingh, F. P., \& Alçiçek, H. (2010). A new cardiid bivalve from the Pliocene Baklan Basin (Turkey) and the origin of modern Ponto-Caspian taxa. Palaeontology, 53, 711-719.

Westaway, R., Guillou, H., Yurtmen, S., Demir, T., Scaillet, S., \& Rowbotham, G. (2005). Constraints on the timing and regional conditions at the start of the present phase of crustal extension in western Turkey, from observations in and around the Denizli region. Geodinamica Acta, 18, 209-238.

Willmann, R. (1982). Biostratigraphisch wichtige Süßwassergastropoden (Prosobranchia, Hydrobiidae) aus dem Neogen des Ägäis-Raumes. Neues Jahrbuch für Geologie und Paläontologie, Abhandlungen, 162, 304-331.
Woodcock, N. H., \& Robertson, A. H. F. (1982). Wrench and thrust tectonics along a Mesozoic-Cenozoic continental margin: Antalya complex, SW Turkey. Journal of the Geological Society London, 139, 147-163.

Zanchi, A., Kissel, C., \& Tapırdamaz, C. (1993). Late Cenozoic and Quaternary brittle continental deformation in western Turkey. Bulletin de la Societe Geologique de France, 164, 507-517.

Publisher's note Springer Nature remains neutral with regard to jurisdictional claims in published maps and institutional affiliations. 